\title{
The Hypoxic Testicle: Physiology and Pathophysiology
}

\author{
Juan G. Reyes, ${ }^{1}$ Jorge G. Farias, ${ }^{2}$ Sebastián Henríquez-Olavarrieta, ${ }^{3}$ \\ Eva Madrid, ${ }^{4}$ Mario Parraga, ${ }^{4}$ Andrea B. Zepeda, ${ }^{2}$ and Ricardo D. Moreno ${ }^{3}$ \\ ${ }^{1}$ Instituto de Química, Facultad de Ciencias, Pontificia Universidad Católica de Valparaíso, 2340000 Valparaíso, Chile \\ ${ }^{2}$ Departamento de Ingeniería Química, Facultad de Ingeniería, Ciencias y Administración, Universidad de La Frontera, \\ 4780000 Temuco, Chile \\ ${ }^{3}$ Departamento de Fisiología, Facultad de Ciencias Biológicas, Pontifica Universidad Católica de Chile, 8320000 Santiago, Chile \\ ${ }^{4}$ Centro de Investigaciones Biomédicas, Escuela de Medicina, Universidad de Valparaíso, 2340000 Valparaíso, Chile
}

Correspondence should be addressed to Juan G. Reyes, jgmonarcas@yahoo.es

Received 5 May 2012; Revised 7 August 2012; Accepted 9 August 2012

Academic Editor: Vincent Pialoux

Copyright (C) 2012 Juan G. Reyes et al. This is an open access article distributed under the Creative Commons Attribution License, which permits unrestricted use, distribution, and reproduction in any medium, provided the original work is properly cited.

\begin{abstract}
Mammalian spermatogenesis is a complex biological process occurring in the seminiferous tubules in the testis. This process represents a delicate balance between cell proliferation, differentiation, and apoptosis. In most mammals, the testicles are kept in the scrotum 2 to $7^{\circ} \mathrm{C}$ below body core temperature, and the spermatogenic process proceeds with a blood and oxygen supply that is fairly independent of changes in other vascular beds in the body. Despite this apparently well-controlled local environment, pathologies such as varicocele or testicular torsion and environmental exposure to low oxygen (hypoxia) can result in changes in blood flow, nutrients, and oxygen supply along with an increased local temperature that may induce adverse effects on Leydig cell function and spermatogenesis. These conditions may lead to male subfertility or infertility. Our literature analyses and our own results suggest that conditions such as germ cell apoptosis and DNA damage are common features in hypoxia and varicocele and testicular torsion. Furthermore, oxidative damage seems to be present in these conditions during the initiation stages of germ cell damage and apoptosis. Other mechanisms like membrane-bound metalloproteinases and phospholipase A2 activation could also be part of the pathophysiological consequences of testicular hypoxia.
\end{abstract}

\section{Introduction}

Life on earth appeared about 3,000 million years ago when there was practically no oxygen in the atmosphere. It only reached its present level in the atmosphere approximately 350 million years ago (carboniferous period), clearly showing that cellular life on earth was well adapted to hypoxic conditions a long time before the present oxygen-dependent organisms appeared on earth [1]. Thus, anoxic oxidative and reductive chemical processes and their associated regulation were inherent in life before the carboniferous period, helping to explain the evolutionary and molecular basis of present marine and terrestrial animal adaptation to hypoxic conditions $[2,3]$. The processes that use oxygen as final electron acceptor in one-electron transference were selected by evolution as a highly efficient mechanism for oxidative processes in cells. These processes, however, inevitably produce reactive oxygen species (ROS) that, in turn, can lead to the formation of reactive nitrogen species (RNS). Both ROS and RNS can modify biomolecules and affect lipids, proteins, and nucleic acids (e.g., [4]).

In multicellular animals, $\mathrm{O}_{2}$ supply to tissues is generally provided by pressure-driven volume flow in a vascular system. Hypoxia, defined as the condition of low oxygen pressure or content in the environment, organism or tissue, can be the result of atmospheric low oxygen pressure (hypobaric hypoxia), low oxygen content in aquatic environments, or, in the case of organisms or tissues, to a decreased $\mathrm{O}_{2}$ exchange with the environment or a decreased $\mathrm{O}_{2}$ supply by the vascular bed.

Most mammals have little tolerance to hypoxia and their response involves the activation of regulatory mechanisms at systemic, tissue, and cellular levels [5]. The mechanisms related to systemic response to hypoxia include an increase in pulmonary ventilation and subsequently a compensatory rise in the capacity of oxygen transport to the different 
tissues by increased erythropoiesis [6-8]. At the cellular level, an induction of glycolytic enzymes and glucose transport is produced under hypoxic conditions. This generates an increase in glycolysis that facilitates the production of ATP by this anaerobic metabolic pathway $[7,8]$. At the tissue level, a hypoxic condition induces neovascularization or angiogenesis (new blood vessel formation from preexisting vessels) which requires a series of events including proliferation, differentiation, and migration of endothelial cells, vessel formation, and vascular maturation. All this is driven by vascular growth factors (e.g., vascular endothelial growth factor, VEGF) [7-10]. The increase in VEGF secretion and the expression of their receptors in cells exposed to hypoxia is mediated by hypoxia-induced factor 1 (HIF-1) $[8,11]$. This is a heterodimeric transcription factor composed of two subunits HIF- $1 \alpha$ and HIF- $1 \beta$ that control the expression of numerous proteins related to the cellular hypoxic response [11-14]. The HIF- $1 \beta$ subunit is a constitutive $90 \mathrm{KDa}$ nuclear protein that does not respond to changes in oxygen level, whereas the HIF- $1 \alpha$ subunit is a $120 \mathrm{KDa}$ hypoxia-inducible protein [14-17]. Under normoxic conditions, HIF- $1 \alpha$ becomes hydroxylated and ubiquitinated and is sent to degradation by the proteasome [15]. HIF-1 $\alpha$ prolyl hydroxylases are $\mathrm{Fe}(\mathrm{II})$ - and 2-oxoglutarate-dependent dioxygenases which require ascorbate and molecular oxygen for their catalytic activity $[13,14]$. In the catalytic center, the ion $\mathrm{Fe}$ (II) can be displaced or substituted by other transition metals such as cobalt, nickel, and manganese, with the loss of its catalytic activity. This inhibition of prolyl hydroxylases and the binding to HIF- $1 \alpha$ itself generate the stabilization of HIF-1 $\alpha$, mimicking a cellular hypoxic situation [18].

A systemic hypoxic condition can be described in many situations such as high altitude flight [19], diving (human or animal) $[20,21]$, chronic obstructive pulmonary disease [22], and sleep apnea (e.g., [23]). Because, however, the relation between the above-mentioned conditions and testicular function has received little attention in the literature (see [24] for sleep apnea), in this paper we will address the consequences for the endocrine homeostasis and sperm output in the testis exposed to environmental or local hypoxia (e.g., varicocele or testicular cord torsion). Thus far, features common to these physiopathological conditions are temperature increase and ROS production, two events that could in part explain the changes in cell endocrine function and the decrease of sperm production in men exposed to hypoxia or with a condition that impairs the blood flow to the testis.

\section{Environmental Hypoxia and Male Reproduction}

With the exception of the unique native population of Himalayas and The Andes, human exposure to high altitude is not a common condition. A deleterious effect on reproductive function has been attributed to exposure to high altitude since the Spanish conquest of America. Some chronicles from the XVI century already stated fertility problems in humans and animals that reached for the first time America's highlands [25]. At present, these fertility changes are observed in mountaineers, workers, and border personnel in situations that imply acute transfer to highlands [26]. However, it seems to be absent in permanent inhabitants of the highlands such as the stable populations of the Andes and Himalaya ranges. These could be at the root of why some of the studies conducted to prove a relationship between highland populations and fertility have often yielded nonconclusive results [2628]. Most of the studies that have shown alterations of the male component of fertility with hypoxia in humans have described low sperm counts, sperm mobility, and decrease in plasma testosterone after several weeks of exposure [2931]. In animal models such as rodents, highly vacuolated Sertoli cells, decreased germ cell numbers, pyknotic germ cell, expansion of testicular blood vessels, Leydig cell number reduction, and changes in testosterone levels have been described in hypobaric hypoxia [32-39].

As the hypoxic testis is the focus of our paper, it is worth mentioning that the main testicular functions are related to endocrine secretion and its associated regulation and to the output of functional sperm cells (spermatogenesis). Whereas the endocrine function is mainly accomplished by Leydig cells in the interstitium (Figure 1), the production of mature functional sperms takes place in several structures in the male reproductive system, including the seminiferous tubules (that releases immature spermatozoa) and the epididymis where the spermatozoa mature and are stored. The seminiferous tubules are the place where proliferation of germ stem cells occurs in contact with the basal membrane and basal part of Sertoli cells, progressing and differentiating through meiosis and spermiogenesis in a centripetal direction toward the lumen of the tubules (Figure 1) [60]. Rat seminiferous tubules are thought to be under an $\mathrm{O}_{2}$ tension lower than the interstitial $\mathrm{O}_{2}$ tension in normal conditions $[12,61]$. In spite of some controversy surrounding the true values of $\mathrm{O}_{2}$ tension in the seminiferous tubules, it is clear that the testicular interstitial $\mathrm{O}_{2}$ tension is approximately $20 \%$ of the testicular artery blood oxygen pressure (i.e., 12 to $15 \mathrm{~mm} \mathrm{Hg}$; [61]). This oxygen tension is expected to decrease under low atmospheric $\mathrm{O}_{2}$ pressure (hypoxia) or under conditions of reduced blood flow to the testis (e.g., varicocele or testicular torsion). Thus, whereas oxygen distribution in the testis is determined by the testicular microvasculature, the access to oxygen by spermatogenic cells seems to be determined mainly by $\mathrm{O}_{2}$ diffusion in the interstitium and seminiferous tubules.

2.1. HIF- $1 \alpha$ and Oxygen Sensing in the Testicles. When cells are exposed to a hypoxic environment or a transient ischemia is induced in rat testicles, a rapid (within minutes) accumulation of HIF- $1 \alpha$ occurs, not accompanied by an increment in HIF- $1 \alpha$ mRNA expression $[62,63]$. HIF- $1 \alpha$ mRNA is expressed in the whole male reproductive tract under physiological oxygen levels $[64,65]$. In the testis of rats exposed to hypobaric hypoxia, HIF-1 $\alpha$ was prominently expressed in the nucleus of pachytene spermatocytes and to a lesser extent in spermatids and in the lumen of seminiferous tubules 




(a)

(b)

FIGURE 1: Histological organization of the seminiferous tubules. The figure shows two microscope images of rat testis: (a) low magnification picture of one seminiferous tubule and seminiferous epithelium containing Sertoli and germ cells at different stages of differentiation. Bar $100 \mu \mathrm{m}$; (b) a seminiferous tubule section indicating germ cells at different stages of differentiation. Bar $25 \mu \mathrm{m}$.

where sperm are located [65]. Out of the vast number of genes induced by HIF-1, one of the most important is VEGF, which has been described in Sertoli and Leydig cells [66]. Its receptor (VEGFR) is present in almost all testicular cell populations, supporting the idea that VEGF could act as a paracrine mitogen and as an angiogenic factor responsible for the modulation of testicular tissue capillarization and testicular capillary permeability [67]. In mice, in vivo application of VEGF to the testis promotes blood capillary formation, but not after the application of antisense oligonucleoties against VEGF [68]. Besides the well-known effects of VEGF as a vascular permeability enhancer and as a mediator of angiogenesis, Hwang et al. observed that VEGF produced an increment in the proliferation of Leydig cells and was an acute inducer of testosterone in a dose-dependent manner $[69,70]$. Thus, the molecular infrastructure and the signaling mechanisms for sensing and triggering of a physiological response are present in testicular cells and, as will be shown below, can at least partially explain the physiological and pathological changes associated to environmental and local hypoxia in the testis.

\subsection{Early Testicular Vascular Changes Induced by Environ-} mental Hypoxia. In mice, a significant increase in detectable interstitial blood vessels was observed 24 hours after the beginning of normobaric hypoxia $[71,72]$. This phenomenon is probably not angiogenic, representing the opening of previously closed shunt vessels. This increase in blood vessels under hypoxia was associated with initiation of vascular cell proliferation. The number of blood vessels detected in the hypoxic testis interstitium continued to increase until day 5 but remained stable after that period $[71,72]$. It is likely that the long-term changes in vasculature ( $>5$ days) are associated with angiogenesis, as reported by Farias et al. [34], which is consistent with a sustained raise in VEGF in that period $[71,72]$.
2.3. Hypoxia and Early Changes in Testicular Steroidogenesis. Gonadotropins released by the hypophysis enter the blood stream to reach the testicle, where Luteinizing hormone (LH) stimulates Leydig cell steroidogenesis in the interstitium, whereas FSH, by stimulation of Sertoli cells, helps to maintain spermatogenesis in the seminiferous tubule. Control mechanisms for FSH secretion seem to be influenced not only by testosterone and its metabolic derivative, estradiol, but also by activins and inhibins produced by Sertoli cells [60].

Little is known about the relationship between hypoxia and steroidogenesis, and the scarce studies performed in humans have been carried out with reduced sample sizes. It has been observed that in a small group of men exposed to an altitude of 4,300 $\mathrm{m}$ above sea level, their plasma testosterone level rose by $30 \%$ after the third day of exposition [31]. In another study in which 10 mountaineers stayed in the Himalayas for a period of 60 days at $5000 \mathrm{~m}$ above sea level, hormonal measures indicated reduced testosterone levels at the end of the period [73].

In experimental mice exposed to normobaric hypoxia, testosterone levels (plasma and intratesticular) were highest at 24 hours for plasma testosterone and 48 hours for intratesticular testosterone. The early increment of both intratesticular and plasma testosterone might be mediated by VEGF, as postulated by Hwang et al. [69] and consistent with a raise in VEGF in mice after $24 \mathrm{hrs}$ of hypoxia [71, 72]. Plasma and testicular testosterone return to normal levels after 48 and 72 hours, respectively $[71,72]$.

These results are in agreement with published data on early testosterone increments in mountaineers exposed to high altitude or in newborns exposed to neonatal hypoxia $[31,74,75]$. Testosterone has a well-known relaxing effect on smooth muscle which can induce a vasodilator effect in minutes [76-78], an effect that, hypothetically, could be part of the hypoxia response mechanisms in the testicles 

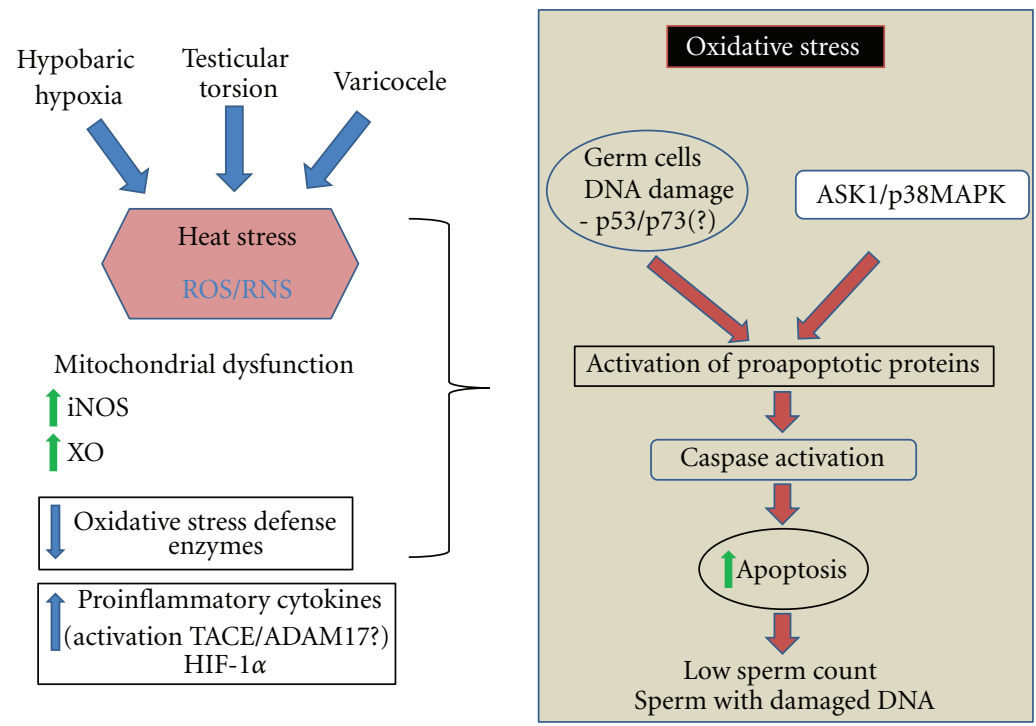

FIGURE 2: Diagram of molecular and cellular events triggered by hypobaric hypoxia (HH), testicular torsion (TT), and varicocele (Var). This model suggests that HH, TT, and Var have a common mechanism of action at the testicular level by inducing oxidative stress owing to an increase in reactive oxygen and nitrogen species (ROS/RNS) formation and impairment in the oxidative defense mechanisms. Experimental evidence points to heat stress in $\mathrm{HH}$ and Var, but this parameter has not been determined in TT. The increase in ROS/RNS is probably owed to mitochondrial dysfunction along with activation of enzymes such as xanthine oxidase (XO) or the inducible nitric oxide synthetase (iNOS). Oxidative stress induces activation of p53, p73, and ASK/p38 MAPK, which stimulate the activation of proapoptotic proteins (e.g., BAX) that in turn will lead to caspase activation and increase in germ cell apoptosis. The induction of proinflammatory cytokines is probably part of the response mechanism to cellular damage.

[71]. Testosterone seems to have a relevant role in high altitude adaptation owing to its identity as an erythropoietic hormone which acts directly on bone marrow at the level of polychromatophilic erythroblasts [79]. Thus, testosterone administration has been shown to stimulate the production of red blood cells in males, especially elderly males, and it is associated with the increment of hemoglobin that occurs during puberty in young men $[80,81]$.

Thus, an early rise in testosterone in hypoxia and its role as a vasodilation agent is consistent with its possible role in early vascular changes in the hypoxic testis, as well as its being a likely coactivator of the erythropoietic response in hypoxia, acting both as a local paracrine hormone and as an endocrine signal toward bone marrow cells.

\subsection{Chronic Intermittent Hypobaric Hypoxia: Testicular Histo-} logical and Endocrine Changes. Hypobaric hypoxia is a stress factor that generates a series of physiological changes in order to compensate for environmental low partial oxygen pressure. Exposure to low levels of environmental oxygen and high altitude tend to trigger chronic mountain sickness (CMS) in humans and animals not genetically adapted (GA) to high altitude, for example, llamas or alpacas. The absence of CMS in GA or nonGA animals or humans appears to be linked to various adaptations involving certain patterns of gene expression $[82,83]$.

With regard to the effects of environmental hypoxia on male infertility, chronic hypoxia induces a state of reversible oligozoospermia in healthy men [30]. Previous studies on nonGA male rats indicated that chronic intermittent hypoxia reduces sperm motility and the sperm count in semen [41, 84]. A reduced sperm count can be related to the increase in germ cell apoptosis promoted by this hypoxic condition $[34,39]$. The same results were observed in male rhesus monkeys [85]. Morphological studies have revealed that chronic hypoxia causes degeneration of the germinal epithelium, folding of the basement membrane, degeneration and detachment of germ cells, changes in lipid droplets in Sertoli cells, and an increase in lipoperoxidation [34, 39]. Other local changes in the testicles have also been observed, including an increase in vascularization, an increase in testicular temperature, a decrease in testicular mass, and an increase in interstitial space $[34,71]$.

The mechanism by which permanent decreases in oxygen supply generate impairment in germ cell development and death is probably mediated by an increase in intratesticular or seminal ROS (Figure 2). Although these molecules have a physiological role in the spermatogenic process, a pathological increase in their numbers would negatively affect the survival and differentiation of germ cells [86].

On the endocrine side, plasma and testicular testosterone in mice are significantly diminished at 20 days of normobaric hypoxia compared with day zero [71], similarly to what has been described in hypobaric hypoxic animals [31, 37]. This effect of testosterone reduction associated with long and intermittent periods of hypoxia has been observed even in patients suffering from obstructive sleep apnea [87] and in long-term exposure to high altitude in humans [73] and is consistent with changes in the Leydig cell population in experimental animals subjected to this condition $[32,34,71]$. 
TABLE 1: Experimental approaches that prevent testicular and sperm damage during environmental hypoxia.

\begin{tabular}{|c|c|c|c|c|}
\hline Hypobaric hypoxia & Treatment & Mechanism & Results versus injury & Reference \\
\hline Acute & Cyproheptadine & 5-HT receptor blocker & 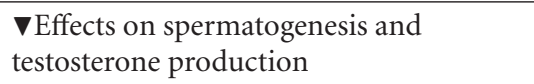 & {$[40]$} \\
\hline Chronic & Caloric restriction & ? & Suppresses early rise in testosterone & {$[31]$} \\
\hline Intermittent & Ascorbic acid & $\begin{array}{l}\boldsymbol{\nabla} \text { Oxidative stress in testis and epididymis } \\
\Delta \text { Glutathione reductase activity in testis } \\
\text { and epididymis } \\
\Delta \text { Sperm count }\end{array}$ & $\begin{array}{l}\text { Reversed the effects of oxidative stress in } \\
\text { testis, epididymis, and sperm cells }\end{array}$ & {$[41]$} \\
\hline Intermittent & $\begin{array}{c}\text { Melatonin } \\
\text { (oral administration) }\end{array}$ & $\begin{array}{l}\text { Prevents oxidative damage of enzymes } \\
\text { like superoxide dismutase, catalase, and } \\
\text { glutathione peroxidase }\end{array}$ & $\begin{array}{l}\text { Protective effect against lipid } \\
\text { peroxidation under oxidative stress and } \\
\text { reduction in sperm motility }\end{array}$ & {$[42]$} \\
\hline Intermittent & $\begin{array}{l}\text { Melatonin } \\
\text { (intraperitoneal } \\
\text { administration) }\end{array}$ & $\begin{array}{l}\boldsymbol{\nabla} \text { Levels of LH and FSH } \\
\text { Inhibition of aromatase }\end{array}$ & $\begin{array}{l}\text { No protective effect in testis, and } \\
\text { epididymis } \\
\text { No prevention of reduction in the } \\
\text { numbers of sperm cells }\end{array}$ & {$[43]$} \\
\hline $\begin{array}{l}\text { Chronic and } \\
\text { intermittent }\end{array}$ & Ibuprofen & Decreases hypoxia-induced vasodilation? & $\begin{array}{l}\text { Protective effect against hypoxia-induced } \\
\text { seminal lipid peroxidation }\end{array}$ & {$[42]$} \\
\hline
\end{tabular}

2.5. The Temperature-ROS Connection and Spermatogenic Cell Damage in Environmentally Hypoxic Testicles. ROS production requires $\mathrm{O}_{2}$ as a substrate. Counter intuitively as it seems, hypoxia, as several studies have reported, can increase total intracellular ROS production in cells and tissues [8893]. Consistently with this, evidence of ROS modification of proteins and nucleic acids has also been reported in yeast exposed to hypoxic conditions [94]. Environmental hypoxia leads to vascular changes that are associated with an increase in testicular temperature $\left(1.5^{\circ} \mathrm{C}\right.$ on average, [35]). This condition was linked to oxidative stress and was prevented by antioxidant treatment $[41,42]$. Although the pathological role of oxidative stress in male reproduction induced by environmental hypoxia seems well established (see also Table 1), the associated rise in temperature needs to be considered for an understanding of the consequences of hypoxia on testicular function. As mentioned before, the changes in subscrotal temperature were relatively mild in hypobaric hypoxia $\left(1.5^{\circ} \mathrm{C}\right.$ on average) [35]. If, however, this condition is to be maintained chronically during the hypoxic period it becomes similar to temperature increases in pathological conditions like varicocele (see below). Thus, in the following paragraphs, we will review experimental testicular hyperthermia albeit that the protocols used have gone from mild temperature changes $\left(35^{\circ} \mathrm{C}\right)$ for $24 \mathrm{hrs}$ to acute $(30 \mathrm{~min})$ severe hyperthermia $\left(43^{\circ} \mathrm{C}\right)$. It is worth noting that the experimental interventions mentioned earlier consist in external temperatures applied to the scrotum. The true intratesticular temperature was in most cases unknown (see [95] for a review).

Heat stress induces general changes in the transcriptome of mice and human testes, and a total of 67 transcripts were found to be heat regulated in C57BL/6 mice [96]. Another study in mice with a heat stress protocol of $35^{\circ} \mathrm{C}$ for $24 \mathrm{~h}$ showed that 225 genes were differentially expressed between fertility-related heat-susceptible and heat-resistant animals [97]. On the other hand, in humans, it was shown that 31 and 36 known proteins were differentially expressed two and nine weeks after heat treatment, respectively [98]. Although the range of functions that the genes upregulated or downregulated by heat is broad, many of these genes are associated with heat stress, cell signaling, and apoptosis.

Under normal conditions, the highest rate of germ cell apoptosis is observed in early zygotene and ending pachytene spermatocytes (stages I and XII for rats and mice). The evaluation of germ cell apoptosis one to two days after heat stress showed a significant increase in apoptosis, mainly in the early (I-IV) and late (XII-XIV) stages. Pachytene spermatocytes, dividing spermatocytes, and early spermatids were the most frequent cell types observed undergoing apoptosis [99]. Eventually, spermatogenesis recovers to levels similar to those in nontreated animals because spermatogonia are relatively heat resistant, with the exception of B-type spermatogonia of rams $[99,100]$ and bulls [101]. Interestingly, isolated haploid germ cells but not somatic cells undergo apoptosis at $37^{\circ} \mathrm{C}$ under the same culture conditions, strongly suggesting that heat stress activates the apoptotic pathway mainly in germ cells [102].

The mechanism by which heat stress induces apoptosis in germ cells has yet to be defined. In rats and monkeys heat stress induces translocation of the proapoptotic protein BAX from the cytoplasm to the mitochondria (Figure 2), where it helps to release cytochrome c [103-107]. During heat stress, caspase- 9 and 3 (hallmarks of apoptosis) become active, and their pharmacological inhibition prevents germ cell death, suggesting that caspases are directly linked to germ cell death after heat stress [104, 105, 108].

In the testis, the generation of ROS seems to be of paramount importance in germ cell apoptosis and DNA damage [109]. At physiological levels, ROS are essential for normal 
reproductive functioning, acting as metabolic intermediates and regulating vascular tone, gene expression, and sperm capacitation $[109,110]$. Heat stress induces oxidative stress, triggering cell survival or apoptosis depending on the cell type and the extent of the insult (Figure 2). This heat stress appears related to ROS-generating enzymes that produce ROS as by-products of their enzymatic activity. Xanthine oxidase (XO) catalyzes the conversion of hypoxanthine and xanthine to uric acid, producing hydrogen peroxide as a by-product, and XO inhibitors suppress testicular germ cell apoptosis induced by experimental cryptorchidism (testis subjected to the core body temperature) [111]. There is a lack of information, however, about whether or not other ROSgenerating enzymes such as cyclooxygenase (COX), lipoxygenase (LOX), NADPH oxidase (NOX), and the mitochondrial NADH-CoQ oxido-reductase are activated after testicular heat stress. In other oxidative processes, nitric oxide (NO) is synthesized intracellularly through the action of a family of nitric oxide synthetase (NOS) enzymes. These NOS enzymes catalyze the NADPH- and $\mathrm{O}_{2}$-dependent oxidation of Larginine to L-citrulline, producing NO [112]. This molecule is a free radical and is chemically more stable and less reactive than other ROS such as the superoxide anion or hydrogen peroxide [113]. Furthermore, NO in the presence of ROS can form the highly reactive oxidant peroxynitrite [114]. In monkey testes, endothelial nitric oxide synthetase (eNOS) and inducible NOS (iNOS) were found to be expressed in Sertoli and germ cells. No obvious alterations in eNOS levels were detected after heat stress, but the levels of iNOS increased three days after heat treatment compared with the controls showing a robust increase in iNOS expression in germ cells [115]. Thus, heat stress seems to induce NO production and it might contribute to oxidative damage in germ cells (Figure 2). The molecular targets that are modified by NO production and the consequences of this RNS in testis physiology and pathophysiology are still unknown, however.

As described above, many studies have been performed on experimental hyperthermia in animals, showing the triggering of apoptosis in pachytene spermatocytes [116, 117]. In contrast, few studies of hyperthermia and its associated physiological and biochemical changes have been performed in isolated cells. The only study found in the literature using prepubertal monkey Sertoli cells [118] reported that adherent junction-associated proteins are downregulated by high temperatures $\left(43^{\circ} \mathrm{C}\right)$. Conversely, vimentin expression is upregulated by high temperatures. These changes in cytoskeletal and junction proteins were thought to be associated with a marked decrease in androgen receptor (AR) expression after heat treatment. As was clearly demonstrated using selective Sertoli cell AR KO mice, testosterone is essential for spermatogenesis through its actions on Sertoli cells $[119,120]$. Thus, Sertoli cell AR downregulation by hyperthermia explains, at least in part, spermatogenic arrest in testis subjected to high temperatures (and hypoxia?). In spite of the mentioned correlation of AR expression and hyperthermia, evidence showing the mechanisms connecting AR downregulation and spermatogenic cell apoptosis under conditions of high temperature is lacking. In relation to testosterone, studies of the effects of high temperature on Leydig cell function and testosterone production are apparently absent in the literature. With regard to isolated germ cells, [121] showed that increasing the incubation temperature of rat pachytene spermatocytes and round spermatids to 37 to $40^{\circ} \mathrm{C}$ increased intracellular $\left[\mathrm{Ca}^{2+}\right]\left(\left[\mathrm{Ca}^{2+}\right] \mathrm{i}\right)$ to levels that modify signaling in these cells [122]. The intracellular $\mathrm{pH}$ in these cells was found to decrease with increasing temperature. These changes occurred within one minute of the increase in temperature and can be classified as early events in the response of these cells to heat stress. Interestingly, the same combination of changes in these cellular parameters (increase in $\left[\mathrm{Ca}^{2+}\right] \mathrm{i}$ and decrease in intracellular $\mathrm{pH}$ ) was associated with apoptotic cells in the testis [123], strongly suggesting that high temperatures per se can set physiological conditions in spermatogenic cells that make them prone to other noxious or proapoptotic stimuli from Sertoli cells. Furthermore, we recently found that a high temperature $\left(40^{\circ} \mathrm{C}\right)$ induced a rapid increase in reactive oxygen and/or nitrogen species in pachytene spermatocytes but not in round spermatids (Pino, Osses, Oyarzun, Farias, Moreno and Reyes, unpublished results), providing the possible noxious stimuli that could differentially trigger cell death in spermatocytes. Thus, oxidative stress seems to be at the root of the cell changes in the environmental hypoxic testicle that lead to spermatogenic cell death. This stress seems to be compounded by the rise in testicular temperature, especially in chronic hypoxia.

Hypoxia, by triggering in most cells and tissues an HIF$1 \alpha$-dependent response, can induce metabolic adaptations but, on the other hand, hypoxia starts a relatively complex spectrum of responses that involves not only HIF-controlled signals and gene expression but also ROS/RNS, AMPK, and PLA2 activation that appear to determine tissue-specific effects of the hypoxic state [124]. In relation these responses, it has been known for almost 20 years that PLA2 and AA seem to play a role in tissue injury and response under hypoxia-reoxygenation situations in animal tissues [125127]. In the testis, Sertoli cells (SCs) produce arachidonic acid (AA) and some of its metabolites in an FSH-regulated manner, [128]. In a SC-derived cell line (TM4), activation of CD95 (Fas), a pathway known to participate in spermatogenic cell apoptosis $[123,129]$, can activate cytosolic PLA and AA release [130]. Our unpublished results (Madrid, Osses, Pino, Oresti, Paillamanque, Moreno and Reyes) show that AA can induce apoptosis in spermatogenic cells, together with increases in intracellular $\mathrm{Ca}^{2+}$ and a lowering of intracellular pH, two proapoptotic conditions in these cells [123]. Thus, although still not tested experimentally, hypoxiainduced $\mathrm{PLA}_{2}$ activation in Sertoli cells and AA release are possible mechanisms by which hypoxia (environmental and local) could also help to trigger spermatogenic cell death in the hypoxic testis.

Some of the cellular and molecular mechanisms of environmental hypoxia-induced sperm and endocrine changes discussed above are apparently corroborated by some treatments that can partially reverse the effects of hypoxia (Tables 1,2 , and 3). Thus, in environmental hypoxia, a serotonin (5-HT) blocker can reverse the effects of hypoxia on spermatogenesis and testosterone production, in agreement with 
TABLE 2: Pharmacological approaches that modify testicular and sperm functional parameters in varicocele.

\begin{tabular}{lccc}
\hline Treatment & Mechanism & Result versus injury \\
\hline Polydeoxyribonucleotides & Adenosine A2A-receptor stimulator & $\boldsymbol{\nabla}$ Histological changes produced by varicocele & Reference \\
Aminoguanidine & Nitric oxide synthase inhibitor & Prevents sperm DNA fragmentation \\
Aminoguanidine & Nitric oxide synthase inhibitor & $\boldsymbol{\Delta}$ Sperm vitality, motility, and morphology & {$[45]$} \\
EGF & Growth factor & $\boldsymbol{\Delta}$ Sperm count and motility & {$[45]$} \\
Melatonin & Antioxidant, hormone & $\boldsymbol{\nabla}$ MDA and Bax levels & {$[46]$} \\
\hline
\end{tabular}

CAT: catalase; GPx: glutathione peroxidase; GSH: glutathione; SOD: superoxide dismutase.

TABLE 3: Treatments that improve and/or prevent testicular and sperm damage in experimental testicular torsion.

\begin{tabular}{|c|c|c|c|}
\hline Treatment & Mechanism & Results versus injury & Reference \\
\hline $\begin{array}{l}\text { Transplanted endotelial progenitor } \\
\text { cells }\end{array}$ & N/A & $\begin{array}{l}\boldsymbol{\nabla} \text { Apoptosis } \\
\text { Prevents histopathological damage }\end{array}$ & {$[48]$} \\
\hline $\begin{array}{l}\text { Pretreatment w/ginkgo biloba (EGb } \\
761 \text { ) }\end{array}$ & Extract of dried leaves & 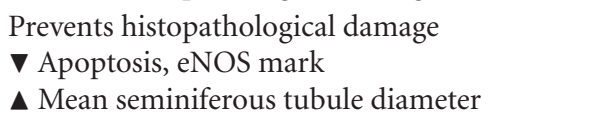 & {$[49]$} \\
\hline $\begin{array}{l}\text { Pretreatment w/sildenafil citrate } \\
(0.7 \mathrm{mg} / \mathrm{kg})\end{array}$ & $\begin{array}{l}\text { Phosphodiesterase } \\
\text { type } 5 \text { inhibitor }\end{array}$ & $\begin{array}{l}\nabla \text { MDA levels and eosinophil counts } \\
\text { Prevents histopathological damage } \\
\Delta \text { GSH, PON1, NO, and blood lymphocyte } \\
\text { counts in plasma }\end{array}$ & {$[50]$} \\
\hline $\begin{array}{l}\text { Pretreatment w/sildenafil citrate } \\
(1.4 \mathrm{mg} / \mathrm{kg})\end{array}$ & $\begin{array}{l}\text { Phosphodiesterase } \\
\text { type } 5 \text { inhibitor }\end{array}$ & $\begin{array}{l}\text { च MDA levels } \\
\Delta \text { PON1, vitamin E, } \beta \text {-carotene in plasma, and } \\
\text { GSH levels }\end{array}$ & {$[50]$} \\
\hline $\begin{array}{l}\text { Pretreatment w/melanocortin } 4 \\
\text { activator }\end{array}$ & Melanocortin analog & $\begin{array}{l}\boldsymbol{\nabla} \text { IL- } 6 \text { and TNF- } \alpha \text {, Bax } \\
\Delta \text { Bcl- } 2 \text { expression, Johnsen's spermatogenesis } \\
\text { score }\end{array}$ & {$[51]$} \\
\hline Rutin & Antioxidant & $\begin{array}{l}\boldsymbol{\nabla} \text { MDA levels } \\
\Delta \text { SOD and CAT activities, Johnsen's } \\
\text { spermatogenesis score }\end{array}$ & {$[52]$} \\
\hline Gradual detorsion & N/A & $\Delta$ SOD and GPx activities & {$[53]$} \\
\hline Molsidomine & Nitric oxide donor & $\begin{array}{l}\text { v MDA levels and Cosentino's score } \\
\text { \ Sonic hedgehog and HIF1- } \alpha \text { expression }\end{array}$ & {$[54]$} \\
\hline Cyclosporine and FK-506 & Immunophilin ligands & $\begin{array}{l}\text { v MDA levels, apoptosis } \\
\Delta \text { CAT, SOD, and Gpx activities }\end{array}$ & {$[55]$} \\
\hline Pretreatment w/trapidil & Vasodilator & Prevent histopathological damage & {$[56]$} \\
\hline Hemin & Iron-containing porphyrin & $\begin{array}{l}\text { V NF- kappaB and ERK levels } \\
\Delta \text { heme oxygenase-1 }\end{array}$ & {$[57]$} \\
\hline Pretreatment w/ethyl pyruvate & $\begin{array}{l}\text { Antioxidant, } \\
\text { anti-inflammatory }\end{array}$ & $\begin{array}{l}\text { v MDA, myeloperoxidase levels and apoptotic } \\
\text { index } \\
\Delta \text { CAT, GSH, Gpx, SOD activities and sperm } \\
\text { count and motility }\end{array}$ & {$[58]$} \\
\hline Pretreatment w/losartan, lisinopril & $\begin{array}{l}\text { Angiotensin II receptor antagonist, } \\
\text { ACE inhibitor }\end{array}$ & $\begin{array}{l}\text { Prevents histopathological damage in } \\
\text { contralateral testis }\end{array}$ & {$[59]$} \\
\hline
\end{tabular}

ROS: reactive oxygen species; GSH: glutathione; SOD: superoxide dismutase; eNOS: endothelial nitric oxide synthetase; MDA: malondialdehyde; CHOP: C/EBP homology protein; CREM $\tau$ : cAMP-responsive element modulator- $\tau$; MCP: monocyte chemotactic protein-1; N/A: not available.

the effects of 5-HT on testicular vasculature and testosterone production [40]. The effect of ibuprofen that appears to decrease oxidative stress has been attributed to its antivasodilatation actions in the testicle [42]. Furthermore, antioxidant treatment can also partially reverse the effects of hypoxia in testis epididymis and sperm [41]. The apparently contradictory results in terms of hypoxic changes in the testis obtained by using melatonin in different routes of administration $[41,42]$ is puzzling, but this compound has both antioxidant and hormonal properties. How 
the administration route systemically affects these two properties of melatonin is unknown.

\section{Local Hypoxia: Varicocele and Testicular Torsion}

3.1. The Hypoxia-ROS-Temperature Connection in Varicocele. An important pathology associated with male subfertility and an increase in intratesticular and seminal ROS levels is varicocele, which is characterized by abnormally dilated veins in the pampiniform plexus, and it has been associated with abnormalities in semen analyses. Varicocele is diagnosed only in humans and it seems to be associated with the erect position whereby one-way valves in the spermatic veins insure the exit of waste products against gravity [131]. Dysfunction of the internal spermatic vein valves with age increases the pressure up to eight times above the physiologic level in the venous drainage, which deviates testicular venous flow to other horizontal routes. This unique biological phenomenon causes hypoxia and oxidative stress, which severely impairs spermatogenesis [132]. A diagnosis of varicocele is made in $35 \%$ of men with primary infertility and in approximately $80 \%$ of men with secondary infertility $[133,134]$. Varicocele can cause tissue hypoxia and related events such as angiogenesis by promoting expression of HIF- $1 \alpha$, which upregulates VEGF and allows expression of different adaptive cellular mechanisms in response to hypoxia [135-137]. HIF$1 \alpha$ has been detected in the cytoplasm of germ cells and vascular endothelium [137]. Furthermore, increased VEGF expression has been observed in testicular endothelial cells in men with varicocele and in the germ cell cytoplasm in rats with experimental varicocele (Figure 2). This elevated expression of VEGF is likely to have a paracrine effect on the testicular microvasculature, inducing the growth of new vessels, as has been observed in men with varicocele [134]. Thus, upregulation of HIF $1 \alpha$ seems a feature common to varicocele, hypobaric hypoxia, and experimental heat stress alike (Figure 2).

An alternative hypothesis, however, is that high temperature rather than intratesticular hypoxia is the main source of oxidative stress in patients with varicocele, which is supported by three lines of evidence: (1) patients with varicocele have a higher scrotal temperature and shorter recovery period after cold stress [138]; (2) varicocelectomy improves semen parameters, probably by reducing testicular temperature and ROS levels and increasing antioxidant activity in the seminal plasma [139-141]; (3) increased scrotal temperature but not varicocele grade correlates well with testicular oxidative stress and apoptosis [142].

It is generally accepted that testicular and seminal ROS levels are important in terms of the deleterious effects of varicocele on male fertility $[109,143-145]$. In fact, $\mathrm{H}_{2} \mathrm{O}_{2}$ applied directly in the testis induces germ cell apoptosis, showing that oxidative stress may directly induce apoptosis in germ cells [146]. ROS levels in semen samples from men with varicocele are significantly higher than those of fertile control men [143, 144, 147], and they are directly related to the degree of varicocele [148]. In this regard, the damage caused by varicocele becomes worse as the time between its first appearance and varicocelectomy increases [149], indicating that the testes have intrinsic mechanisms for avoiding permanent damage under certain conditions, but that damage is inevitable when the hypoxia (or elevated temperature) is sustained over time. Changes in testicular tissue have been described in both humans and animal models of varicocele, particularly in rats, producing smaller testicles with a decrease in Leydig cell functioning and a low total sperm count but with no abnormalities in the motility or morphology of the spermatozoa [150-152].

Different intracellular pathways are activated downstream of ROS production, among which the ASK1/p38MAPK pathway has been shown to be important in germ cell apoptosis after heat stress [153-155]. p53, a master gene in apoptosis and a target of p38 MAPK (Figure 2), is activated in rats with experimental varicocele [156]. In fact, the proapoptotic gene Bax, which is a transcriptional target of p53, is upregulated in experimental varicocele in animal models [47, 157-159]. In addition, the downregulation of $\mathrm{Bcl}-2$ and increased expression of caspase- 9 and activated caspase- 3 in the ipsilateral testis at eight and 12 weeks after the onset of varicocele has been documented, indicating gradually increased testicular tissue apoptosis through the intrinsic pathway [158]. Therefore, elevated oxidative stress may lead to an elevated rate of germ cell apoptosis, which could explain the decrease in sperm count reported in infertile patients with varicocele.

3.2. Testicular Torsion: Hypoxia-ROS and Inflammation. Testicular torsion is a urological emergency condition causing pain and eventually leading to total loss of the testis [160, 161]. It consists in the twist or rotation of the vascular pedicle, and the damage to the testis depends on the degree of ischemia/reperfusion. It occurs annually in $1 / 4,000$ males younger than 25 , affecting $1 / 160$ males by the age of 25 $[160,161]$. Animal model studies have shown that 720 degree torsion induces ischemia sufficient to disrupt the seminiferous epithelium [162-164]. Testicular salvage depends on the degree of torsion and on the time that has elapsed until repair. Detorsion within 6, 12, and 24 hours of torsion results in a salvage rate of $90 \%, 50 \%$, and less than $10 \%$, respectively [165]. Experimental testicular ischemia/reperfusion (IR) (e.g., torsion/detorsion) in rats and/or mice induced a decrease in germ cells, vacuolization of the seminiferous epithelium, decreases in sperm production, and germ cell apoptosis [162-167], a pattern of effects very similar to those of chronic environmental hypoxia, as discussed above. Several studies have pointed out the importance of ROS production in the onset of testicular IR response, as evaluated by thiobarbituric acid reactive substances (TBARSs) or 8isoprostane levels [146, 168, 169]. Interestingly, IR promotes the recruitment of neutrophils to subtunical venules in the testis. Since neutrophils are a source of ROS in many other conditions, it is possible that their presence contributes to oxidative stress, which in turn contributes to germ cell DNA damage and germ cell demise by either apoptosis or necrosis $[146,168,170]$. IR induces several bona fide 
apoptosis markers such as DNA fragmentation, activation of caspase-3, caspase-9, and release of cytochrome C from mitochondria and upregulation of BAX $[166,171,172]$. Although general caspase inhibitor and caspase-9 inhibitor prevent germ cell apoptosis in IR testis, it seems that necrosis may also contribute to germ cell demise [173]. In fact, germ cells can trigger both the necrotic and the apoptotic program depending on the stimuli and the time that has elapsed since the injury [170]. Thus it is possible that germ cell necrosis may be an early stimulus in order to recruit neutrophils that eventually promote oxidative stress and the induction of apoptosis.

IR produces an increase in the proinflammatory cytokines TNF $\alpha$ and IL-1 $\beta$ (Figure 2), which suggests a role for these cytokines as early mediators of injury in the testis [169]. Upregulation of TNF $\alpha$ and IL- $1 \beta$ is detected as early as $0.5 \mathrm{~h}$ after IR in mice testes, and this precedes the activation of $\mathrm{c}$ jun N-terminal kinase (JNK) along with two downstream transcription factors; ATF-2 and c-jun in intratesticular blood vessels. E-selectin is a transcriptional target of ATF-2 and c-jun, which could explain its upregulation in IR testes $[146,168,169]$. These results suggest that an increase in TNF $\alpha$ and/or IL- $1 \beta$ after IR of the testis stimulates the activation of the JNK signaling pathway leading to the expression of E selectin in endothelial cells and ultimately neutrophil recruitment. Interestingly, TNF $\alpha$ and/or IL-1 $\beta$ can recruit neutrophils in parenchymal testis veins, suggesting the crucial role of these cytokines in the response of testes after IR insult $[169,174]$. TNF $\alpha$ is expressed as a transmembrane protein in pachytene spermatocytes, round spermatids, and testicular macrophages [175]. Consequently, the release of $\mathrm{TNF} \alpha$ from the cell surface (shedding of the extracellular domain) seems to be an important step in the molecular cascade activated in IR.

The family of membrane-bound metallo proteinases known as metalloproteases and disintegrins (ADAMs) has a central role in juxta/paracrine and autocrine signaling by controlling the ectodomain shedding of different ligands and receptors such as epidermal growth factor (EGF) or TNF $\alpha$ [176]. We have found that ADAM17, the main sheddase of $\mathrm{TNF} \alpha$, is expressed in germ cells, and its activity is necessary to induce apoptosis in physiological conditions [177]. In addition, ADAM17 and ADAM10 are upregulated after genotoxic damage and their pharmacological inhibition prevents germ cell apoptosis $[178,179]$. What is more, significantly higher levels of $\mathrm{TNF} \alpha$ have been found in semen samples from infertile patients as compared with controls, suggesting a role for this cytokine in male fertility in general and specifically in IR-induced pathophysiological changes in the testis [180-182]. Therefore, it is not far-fetched to propose hypothetically that IR associated with testicular torsion could induce activation of ADAM17 and shedding of TNF $\alpha$ as a primary response to hypoxia and oxidative stress.

A range of pharmacological agents can diminish the deleterious effects of varicocele and testicular torsion on several testicular and semen parameters (Tables 2 and 3). In spite of the pharmacological diversity observed in those studies, however, a certain pattern does emerge from the studies cited in Tables 1, 2, and 3. First, antioxidants improve testicular function in environmental and local hypoxia, in agreement with the proposed role of ROS in testicular pathogenesis in these conditions. Second, the possible protective role of the cAMP signaling pathway is strongly suggested by the studies performed on varicocele and testicular torsion. In organ models of IR (liver, heart) the cAMP signaling pathway has been shown to be protective in IR-induced cell apoptosis $[183,184]$. Interestingly, no such approach has been tested in environmental hypoxia studies. Third, a possible role of NO is suggested by the studies in varicocele and testicular torsion, although the results in these pathologies are contradictory. Again, no studies on the role of NO in testicular effects have been performed on environmental hypoxia.

\section{Concluding Remarks}

The available data suggest that oxidative and heat stresses are common features of hypobaric hypoxia, varicocele, and testicular torsion. These conditions induce also the activation of the antioxidant defence mechanisms that once overflown promotes activation of apoptosis and DNA damages in the developing germ cells. It is unknown, however, whether heat stress is the cause or consequence of these pathological conditions. Experimental evidence clearly shows that experimental heat stress mimics some of the pathways and cellular responses observed in hypobaric hypoxia, varicocele, and testicular torsion, but there is still a lack of direct evidence about the real contribution of this parameter to these pathological conditions.

Some of the cellular and molecular mechanisms of environmental hypoxia-induced sperm and endocrine changes discussed above seem to be corroborated by some treatments that can partially reverse the effects of hypoxia (Tables 1 , 2 , and 3). New experimental evidence suggests, however, that previously overlooked molecules such as AMPK, PLA2, arachidonic acid, and ADAM17 may be important players in the onset of testicular damage in the hypoxic testis, and therefore they could constitute new pharmacological targets in the design of experimental strategies to prevent germ cell damage and decrease fertility under these conditions.

\section{Acknowledgment}

Part of this work was supported by Grants FONDECYT 1110267 awarded to J. G. Reyes and 1110778 to R. D. Moreno and by funds from VRIEA-PUCV.

\section{References}

[1] R. Wayne, Chemistry of Atmospheres, Oxford Science Publication, Clarendon Press, Oxford, UK, 1985.

[2] P. Hochachka, Living without Oxygen, Harvard University Press, London, UK, 1980.

[3] J. L. Rupert and P. W. Hochachka, "Genetic approaches to understanding human adaptation to altitude in the Andes," Journal of Experimental Biology, vol. 204, no. 18, pp. 31513160, 2001. 
[4] B. D'Autréaux and M. B. Toledano, "ROS as signalling molecules: mechanisms that generate specificity in ROS homeostasis," Nature Reviews Molecular Cell Biology, vol. 8, no. 10, pp. 813-824, 2007.

[5] R. M. Leach and D. F. Treacher, "Oxygen transport-2. Tissue hypoxia," British Medical Journal, vol. 317, no. 7169, pp. 1370-1373, 1998.

[6] R. Germack, F. Leon-Velarde, R. Valdes De La Barra, J. Farias, G. Soto, and J. P. Richalet, "Effect of intermittent hypoxia on cardiovascular function, adrenoceptors and muscarinic receptors in Wistar rats," Experimental Physiology, vol. 87, no. 4, pp. 453-460, 2002.

[7] K. Abdulmalek, F. Ashur, N. Ezer, Y. Fengchun, S. Magder, and S. N. A. Hussain, "Differential expression of Tie-2 receptors and angiopoietins in response to in vivo hypoxia in rats," American Journal of Physiology, vol. 281, no. 3, pp. L582L590, 2001.

[8] H. H. Marti and W. Risau, "Systemic hypoxia changes the organ-specific distribution of vascular endothelial growth factor and its receptors," Proceedings of the National Academy of Sciences of the United States of America, vol. 95, no. 26, pp. 15809-15814, 1998.

[9] N. P. Fam, S. Verma, M. Kutryk, and D. J. Stewart, "Clinician guide to angiogenesis," Circulation, vol. 108, no. 21, pp. 26132618, 2003.

[10] C. Michiels, "Endothelial cell functions," Journal of Cellular Physiology, vol. 196, no. 3, pp. 430-443, 2003.

[11] G. L. Semenza, "Hypoxia-inducible factor 1: control of oxygen homeostasis in health and disease," Pediatric Research, vol. 49, no. 5, pp. 614-617, 2001.

[12] A. J. Giaccia, M. C. Simon, and R. Johnson, "The biology of hypoxia: the role of oxygen sensing in development, normal function, and disease," Genes and Development, vol. 18, no. 18, pp. 2183-2194, 2004.

[13] G. L. Semenza, "Hydroxylation of HIF-1: oxygen sensing at the molecular level," Physiology, vol. 19, no. 4, pp. 176-182, 2004.

[14] R. K. Bruick, "Oxygen sensing in the hypoxic response pathway: regulation of the hypoxia-inducible transcription factor," Genes and Development, vol. 17, no. 21, pp. 2614-2623, 2003.

[15] C. W. Pugh and P. J. Ratcliffe, "Regulation of angiogenesis by hypoxia: role of the HIF system," Nature Medicine, vol. 9, no. 6, pp. 677-684, 2003.

[16] R. H. Wenger, "Cellular adaptation to hypoxia: $\mathrm{O}_{2}$-sensing protein hydroxylases, hypoxia-inducible transcription factors, and $\mathrm{O}_{2}$-regulated gene expression," FASEB Journal, vol. 16, no. 10, pp. 1151-1162, 2002.

[17] G. L. Wang and G. L. Semenza, "Purification and characterization of hypoxia-inducible factor 1," Journal of Biological Chemistry, vol. 270, no. 3, pp. 1230-1237, 1995.

[18] Y. Yuan, G. Hilliard, T. Ferguson, and D. E. Millhorn, "Cobalt inhibits the interaction between hypoxia-inducible factor- $\alpha$ and von Hippel-Lindau protein by direct binding to hypoxiainducible factor- $\alpha$," Journal of Biological Chemistry, vol. 278, no. 18, pp. 15911-15916, 2003.

[19] M. P. Samuels, "The effects of flight and altitude," Archives of Disease in Childhood, vol. 89, no. 5, pp. 448-455, 2004.

[20] P. Lindholm and C. E. G. Lundgren, "The physiology and pathophysiology of human breath-hold diving," Journal of Applied Physiology, vol. 106, no. 1, pp. 284-292, 2009.

[21] P. W. Hochachka, "Molecular mechanisms of defense against oxygen lack," Undersea Biomedical Research, vol. 16, no. 5, pp. 375-379, 1989.
[22] B. D. Kent, P. D. Mitchell, and W. T. Mcnicholas, "Hypoxemia in patients with COPD: cause, effects, and disease progression," International Journal of COPD, vol. 6, no. 1, pp. 199208, 2011.

[23] L. Lavie, "Oxidative stress inflammation and endothelial dysfunction in obstructive sleep apnea," Frontiers in Bioscience, vol. 4, pp. 1391-1403, 2012.

[24] R. Luboshitzky, A. Aviv, A. Hefetz et al., "Decreased pituitarygonadal secretion in men with obstructive sleep apnea," Journal of Clinical Endocrinology and Metabolism, vol. 87, no. 7, pp. 3394-3398, 2002.

[25] G. F. Gonzales, "Peruvian contributions to the study on human reproduction at high altitude: from the chronicles of the Spanish conquest to the present," Respiratory Physiology and Neurobiology, vol. 158, no. 2-3, pp. 172-179, 2007.

[26] J. P. Richalet, M. V. Donoso, D. Jiménez et al., "Chilean miners commuting from sea level to $4500 \mathrm{~m}$ : a prospective study," High Altitude Medicine and Biology, vol. 3, no. 2, pp. 159-166, 2002.

[27] A. E. Abelson, T. S. Baker, and P. T. Baker, "Altitude, migration and fertility in the Andes," Social Biology, vol. 21, no. 1, pp. 12-27, 1974.

[28] V. J. Vitzthum and A. D. Wiley, "The proximate determinants of fertility in populations exposed to chronic hypoxia," High Altitude Medicine and Biology, vol. 4, no. 2, pp. 125-139, 2003.

[29] A. Okumura, H. Fuse, Y. Kawauchi, I. Mizuno, and T. Akashi, "Changes in male reproductive function after high altitude mountaineering," High Altitude Medicine and Biology, vol. 4, no. 3, pp. 349-353, 2003.

[30] V. Verratti, F. Berardinelli, C. Di Giulio et al., "Evidence that chronic hypoxia causes reversible impairment on male fertility," Asian Journal of Andrology, vol. 10, no. 4, pp. 602606, 2008.

[31] K. E. Barnholt, A. R. Hoffman, P. B. Rock et al., "Endocrine responses to acute and chronic high-altitude exposure $(4,300$ meters): modulating effects of caloric restriction," American Journal of Physiology, vol. 290, no. 6, pp. E1078-E1088, 2006.

[32] J. R. Gosney, "Effects of hypobaric hypoxia on the Leydig cell population of the testis of the rat," Journal of Endocrinology, vol. 103, no. 1, pp. 59-62, 1984.

[33] H. M. Biswas, M. C. Boral, and A. K. Ghosh, "Effect of hypobaric hypoxia on spermatogenesis, Leydig cells and delta 5-3 beta-hydroxysteroid dehydrogenase activity in toad," Indian Journal of Physiology and Pharmacology, vol. 29, no. 3, pp. 139-145, 1985.

[34] J. G. Farias, E. Bustos-Obregón, R. Orellana, J. L. Bucarey, E. Quiroz, and J. G. Reyes, "Effects of chronic hypobaric hypoxia on testis histology and round spermatid oxidative metabolism," Andrologia, vol. 37, no. 1, pp. 47-52, 2005.

[35] J. G. Farías, E. Bustos-Obregón, and J. G. Reyes, "Increase in testicular temperature and vascularization induced by hypobaric hypoxia in rats," Journal of Andrology, vol. 26, no. 6, pp. 693-697, 2005.

[36] E. Bustos-Obregón, C. Esveile, J. Contreras, I. Maurer, and L. Sarabia, "Effects of chronic simulated hypobaric hypoxia on mouse spermatogenesis," International Journal of Morphology, vol. 24, no. 3, pp. 481-488, 2006.

[37] J. G. Farias, E. Bustos-Obregón, P. J. Tapia et al., "Time course of endocrine changes in the hypophysis-gonad axis induced by hypobaric hypoxia in male rats," Journal of Reproduction and Development, vol. 54, no. 1, pp. 18-21, 2008. 
[38] O. N. Shevantaeva and Y. I. Kosyuga, "Effect of acute hypobaric hypoxia on spermatogenesis and lactate concentration in testicular tissue of male albino rats," Bulletin of Experimental Biology and Medicine, vol. 141, no. 1, pp. 20-22, 2006.

[39] W. Liao, M. Cai, J. Chen et al., "Hypobaric hypoxia causes deleterious effects on spermatogenesis in rats," Reproduction, vol. 139, no. 6, pp. 1031-1038, 2010.

[40] G. F. Gonzales, L. Rodriguez, J. Valera, E. Sandoval, and M. Garcia-Hjarles, "Prevention of high altitude-induced testicular disturbances by previous treatment with cyproheptadine in male rats," Archives of Andrology, vol. 24, no. 2, pp. 201205, 1990.

[41] J. G. Farias, M. Puebla, A. Acevedo et al., "Oxidative stress in rat testis and epididymis under intermittent hypobaric hypoxia: protective role of ascorbate supplementation," Journal of Andrology, vol. 31, no. 3, pp. 314-321, 2010.

[42] A. Vargas, E. Bustos-Obregón, and R. Hartley, "Effects of hypoxia on epididymal sperm parameters and protective role of ibuprofen and melatonin," Biological Research, vol. 44, no. 2, pp. 161-167, 2011.

[43] J. G. Farías, A. B. Zepeda, and G. M. Calaf, "Melatonin protects the heart, lungs and kidneys from oxidative stress under intermittent hypobaric hypoxia in rats," Biological Research, vol. 45, no. 1, pp. 81-85, 2012.

[44] S. Arena, L. Minutoli, F. Arena et al., "Polydeoxyribonucleotide administration improves the intra-testicular vascularization in rat experimental varicocele," Fertility and Sterility, vol. 97, no. 1, pp. 165-168, 2012.

[45] M. Abbasi, R. Alizadeh, F. Abolhassani et al., "Effect of aminoguanidine in sperm DNA fragmentation in varicocelized rats: role of nitric oxide," Reproductive Sciences, vol. 18, no. 6, pp. 545-550, 2011.

[46] D. Cheng, X. M. Zheng, S. W. Li, Z. W. Yang, and L. Q. Hu, "Effects of epidermal growth factor on sperm content and motility of rats with surgically induced varicoceles," Asian Journal of Andrology, vol. 8, no. 6, pp. 713-717, 2006.

[47] R. Onur, A. Semerciöz, I. Orhan, and H. Yekeler, "The effects of melatonin and the antioxidant defence system on apoptosis regulator proteins (Bax and $\mathrm{Bcl}-2$ ) in experimentally induced varicocele," Urological Research, vol. 32, no. 3, pp. 204-208, 2004.

[48] P. Cao, J. X. Xue, R. P. Jia et al., "Effects of endothelial progenitor cells on spermatogenic functions in testicular detorsion in rats," Zhonghua yi xue za zhi, vol. 91, no. 30, pp. 2135-2138, 2011.

[49] M. Kanter, "Protective effects of Ginkgo biloba (EGb 761) on testicular torsion/detorsion-induced ischemia-reperfusion injury in rats," Experimental and Molecular Pathology, vol. 91, no. 3, pp. 708-713, 2011.

[50] H. Yildiz, A. S. Durmuş, H. Şimşek, and I. Yaman, "Effects of sildenafil citrate on torsion/detorsion-induced changes in red blood cell and plasma lipid peroxidation, antioxidants, and blood hematology of male rats," European Journal of Obstetrics Gynecology and Reproductive Biology, vol. 159, no. 3, pp. 359-363, 2011.

[51] L. Minutoli, F. Squadrito, P. A. Nicotina et al., "Melanocortin 4 receptor stimulation decreases pancreatitis severity in rats by activation of the cholinergic anti-inflammatory pathway," Critical Care Medicine, vol. 39, no. 5, pp. 1089-1096, 2011.

[52] S. M. Wei, Z. Z. Yan, and J. Zhou, "Protective effect of rutin on testicular ischemia-reperfusion injury," Journal of Pediatric Surgery, vol. 46, no. 7, pp. 1419-1424, 2011.
[53] B. Akçora, M. E. Altuğ, A. Balci et al., "Gradual detorsion of torsioned rat testis attenuates ischemia reperfusion injury," Journal of Pediatric Surgery, vol. 43, no. 10, pp. 1879-1884, 2008.

[54] A. I. Dokucu, H. Ozturk, H. Ozturk, M. C. Tuncer, and F. Yilmaz, "The effects of molsidomine on hypoxia inducible factor alpha and Sonic hedgehog in testicular ischemia/reperfusion injury in rats," International Urology and Nephrology, vol. 41, no. 1, pp. 101-108, 2009.

[55] B. G. Nezami, S. Rahimpour, T. Gholipour et al., "Protective effects of immunophilin ligands on testicular torsion/detorsion damage in rats," International Urology and Nephrology, vol. 41, no. 1, pp. 93-99, 2009.

[56] M. Bozlu, D. Acar, S. Cayan, S. Aktas, and A. Tunckiran, "Protective effect of trapidil on long-term histologic damage in a rat model of testicular ischemia-reperfusion injury," World Journal of Urology, vol. 27, no. 1, pp. 117-122, 2009.

[57] S. Yang, H. J. Shih, Y. C. Chow, P. S. Tsai, and C. J. Huang, "Hemin induced heme oxygenase-1 over expression involves nuclear factor-E2 related factor-2, nuclear factor- $\kappa \mathrm{B}$ and extracellular regulated kinase: an experimental study in a testicular torsion-detorsion rodent model," Journal of Urology, vol. 179, no. 6, pp. 2456-2463, 2008.

[58] S. Payabvash, S. Kiumehr, S. M. Tavangar, and A. R. Dehpour, "Ethyl pyruvate reduces germ cell-specific apoptosis and oxidative stress in rat model of testicular torsion/detorsion," Journal of Pediatric Surgery, vol. 43, no. 4, pp. 705-712, 2008.

[59] G. Gokce, H. Karboga, E. Yildiz, S. Ayan, and Y. Gultekin, "Effect of angiotensin-converting enzyme inhibition and angiotensin II type 1 receptor blockade on apoptotic changes in contralateral testis following unilateral testicular torsion," International Urology and Nephrology, vol. 40, no. 4, pp. 989995, 2008.

[60] Y. Clermont, "Kinetics of spermatogenesis in mammals: seminiferous epithelium cycle and spermatogonial renewal," Physiological Reviews, vol. 52, no. 1, pp. 198-236, 1972.

[61] M. J. Free, G. A. Schluntz, and R. A. Jaffe, "Respiratory gas tensions in tissues and fluids of the male rat reproductive tract," Biology of Reproduction, vol. 14, no. 4, pp. 481-488, 1976.

[62] U. R. Jewell, I. Kvietikova, A. Scheid, C. Bauer, R. H. Wenger, and M. Gassmann, "Induction of HIF-1alpha in response to hypoxia is instantaneous," The FASEB Journal, vol. 15, no. 7, pp. 1312-1314, 2001.

[63] J. D. Powell, R. Elshtein, D. J. Forest, and M. A. Palladino, "Stimulation of hypoxia-inducible factor-1 alpha (HIF-1 $\alpha$ ) protein in the adult rat testis following ischemic injury occurs without an increase in HIF- $1 \alpha$ messenger RNA expression," Biology of Reproduction, vol. 67, no. 3, pp. 995-1002, 2002.

[64] M. A. Palladino, J. D. Powell, N. Korah, and L. Hermo, "Expression and localization of hypoxia-inducible factor-1 subunits in the adult rat epididymis," Biology of Reproduction, vol. 70, no. 4, pp. 1121-1130, 2004.

[65] H. H. Marti, D. M. Katschinski, K. F. Wagner, L. Schäffer, B. Stier, and R. H. Wenger, "Isoform-specific expression of hypoxia-inducible factor- $1 \alpha$ during the late stages of mouse spermiogenesis," Molecular Endocrinology, vol. 16, no. 2, pp. 234-243, 2002.

[66] A. Nalbandian, L. Dettin, M. Dym, and N. Ravindranath, "Expression of vascular endothelial growth factor receptors during male germ cell differentiation in the mouse," Biology of Reproduction, vol. 69, no. 3, pp. 985-994, 2003. 
[67] S. Ergün, N. Kiliç, W. Fiedler, and A. K. Mukhopadhyay, "Vascular endothelial growth factor and its receptors in normal human testicular tissue," Molecular and Cellular Endocrinology, vol. 131, no. 1, pp. 9-20, 1997.

[68] G. S. Marchand, N. Noiseux, J. F. Tanguay, and M. G. Sirois, "Blockade of in vivo VEGF-mediated angiogenesis by antisense gene therapy role of Flk-1 and Flt-1 receptors," American Journal of Physiology, vol. 282, no. 1, pp. H194-H204, 2002.

[69] G. S. Hwang, S. W. Wang, W. M. Tseng, C. H. Yu, and P. S. Wang, "Effect of hypoxia on the release of vascular endothelial growth factor and testosterone in mouse TM3 Leydig cells," American Journal of Physiology, vol. 292, no. 6, pp. E1763-E1769, 2007.

[70] G.-S. Hwang, S.-T. Chen, T.-J. Chen, and S.-W. Wang, "Effects of hypoxia on testosterone release in rat Leydig cells," American Journal of Physiology, vol. 297, no. 5, pp. E1039E1045, 2009.

[71] E. Madrid, Effect of normobaric hypoxia on the testis: vascularization, proliferation and steroidogenesis: a murine model [Ph.D. thesis], Universidad de Granada, 2011, https://www .educacion.gob.es/teseo/.

[72] E. M. Madrid, J. G. Reyes, P. V. Crespo, J. M. Hernández García, S. San Martín, and M. Parraga, "Effect of normobaric hypoxia on the testis in a murine model," Andrología. In press.

[73] A. Benso, F. Broglio, G. Aimaretti et al., "Endocrine and metabolic responses to extreme altitude and physical exercise in climbers," European Journal of Endocrinology, vol. 157, no. 6, pp. 733-740, 2007.

[74] P. Boksa and Y. Zhang, "Global birth hypoxia increases the neonatal testosterone surge in the rat," Neuroendocrinology, vol. 88, no. 4, pp. 266-275, 2008.

[75] G. F. Gonzales, "Hemoglobin and testosterone: importance on high altitude acclimatization and adaptation," Revista Peruana de Medicina de Experimental y Salud Publica, vol. 28, no. 1, pp. 92-100, 2011.

[76] C. E. Costarella, J. N. Stallone, G. W. Rutecki, and F. C. Whittier, "Testosterone causes direct relaxation of rat thoracic aorta," Journal of Pharmacology and Experimental Therapeutics, vol. 277, no. 1, pp. 34-39, 1996.

[77] H. Honda, T. Unemoto, and H. Kogo, "Different mechanisms for testosterone-induced relaxation of aorta between normotensive and spontaneously hypertensive rats," Hypertension, vol. 34, no. 6, pp. 1232-1236, 1999.

[78] C. M. Webb, D. L. Adamson, D. De Zeigler, and P. Collins, "Effect of acute testosterone on myocardial ischemia in men with coronary artery disease," American Journal of Cardio$\log y$, vol. 83, no. 3, pp. 437-439, 1999.

[79] G. F. Gonzales, V. Tapia, M. Gasco, J. Rubio, and C. GonzalesCastañeda, "High serum zinc and serum testosterone levels were associated with excessive erythrocytosis in men at high altitudes," Endocrine, vol. 40, no. 3, pp. 472-480, 2011.

[80] N. Bassil, S. Alkaade, and J. E. Morley, "The benefits and risks of testosterone replacement therapy: a review," Therapeutics and Clinical Risk Management, vol. 5, no. 1, pp. 427-448, 2009.

[81] A. D. Coviello, B. Kaplan, K. M. Lakshman, T. Chen, A. B. Singh, and S. Bhasin, "Effects of graded doses of testosterone on erythropoiesis in healthy young and older men," Journal of Clinical Endocrinology and Metabolism, vol. 93, no. 3, pp. 914-919, 2008.
[82] L. Huicho, G. Xing, C. Qualls et al., "Abnormal energy regulation in early life: childhood gene expression may predict subsequent chronic mountain sickness," BMC Pediatrics, vol. 8, article 47, 2008.

[83] F. León-Velarde and O. Mejía, "Gene expression in chronic high altitude diseases," High Altitude Medicine and Biology, vol. 9, no. 2, pp. 130-139, 2008.

[84] M. Cikutovic, N. Fuentes, and E. Bustos-Obregón, "Effect of intermittent hypoxia on the reproduction of rats exposed to high altitude in the Chilean Altiplano," High Altitude Medicine and Biology, vol. 10, no. 4, pp. 357-363, 2009.

[85] D. K. Saxena, "Effect of hypoxia by intermittent altitude exposure on semen characteristics and testicular morphology of male rhesus monkeys," International Journal of Biometeorology, vol. 38, no. 3, pp. 137-140, 1995.

[86] S. Amaral, P. J. Oliveira, and J. Ramalho-Santos, "Diabetes and the impairment of reproductive function: possible role of mitochondria and reactive oxygen species," Current Diabetes Reviews, vol. 4, no. 1, pp. 46-54, 2008.

[87] P. Y. Liu, I. D. Caterson, R. R. Grunstein, and D. J. Handelsman, "Androgens, obesity, and sleep-disordered breathing in men," Endocrinology and Metabolism Clinics of North America, vol. 36, no. 2, pp. 349-363, 2007.

[88] N. S. Chandel, E. Maltepe, E. Goldwasser, C. E. Mathieu, M. C. Simon, and P. T. Schumacker, "Mitochondrial reactive oxygen species trigger hypoxia-induced transcription," Proceedings of the National Academy of Sciences of the United States of America, vol. 95, no. 20, pp. 11715-11720, 1998.

[89] R. D. Guzy, B. Hoyos, E. Robin et al., "Mitochondrial complex III is required for hypoxia-induced ROS production and cellular oxygen sensing," Cell Metabolism, vol. 1, no. 6, pp. 401-408, 2005.

[90] K. D. Mansfield, R. D. Guzy, Y. Pan et al., "Mitochondrial dysfunction resulting from loss of cytochrome $\mathrm{c}$ impairs cellular oxygen sensing and hypoxic HIF- $\alpha$ activation," Cell Metabolism, vol. 1, no. 6, pp. 393-399, 2005.

[91] R. D. Guzy and P. T. Schumacker, "Oxygen sensing by mitochondria at complex III: the paradox of increased reactive oxygen species during hypoxia," Experimental Physiology, vol. 91, no. 5, pp. 807-819, 2006.

[92] T. P. Cash, Y. Pan, and M. C. Simon, "Reactive oxygen species and cellular oxygen sensing," Free Radical Biology and Medicine, vol. 43, no. 9, pp. 1219-1225, 2007.

[93] F. Bodea, A. Bocea, and N. Decea, "L-carnitine decreases oxidative stress induced by experimental hypobaric hypoxia," Pediatric Endocrinology, Diabetes and Metabolism, vol. 16, no. 2, pp. 78-81, 2010.

[94] R. Dirmeier, K. M. O’Brien, M. Engle, A. Dodd, E. Spears, and R. O. Poyton, "Exposure of yeast cells to anoxia induces transient oxidative stress: implications for the induction of hypoxic genes," Journal of Biological Chemistry, vol. 277, no. 38, pp. 34773-34784, 2002.

[95] A. Morgentaler, B. C. Stahl, and Y. Yin, “Testis and temperature: an historical, clinical, and research perspective," Journal of Andrology, vol. 20, no. 2, pp. 189-195, 1999.

[96] Y. Li, Q. Zhou, R. Hively, L. Yang, C. Small, and M. D. Griswold, "Differential gene expression in the testes of different murine strains under normal and hyperthermic conditions," Journal of Andrology, vol. 30, no. 3, pp. 325-337, 2009.

[97] K. M. Cammack, E. Antoniou, L. Hearne, and W. R. Lamberson, "Testicular gene expression in male mice divergent for fertility after heat stress," Theriogenology, vol. 71, no. 4, pp. 651-661, 2009. 
[98] H. Zhu, Y. Cui, J. Xie et al., "Proteomic analysis of testis biopsies in men treated with transient scrotal hyperthermia reveals the potential targets for contraceptive development," Proteomics, vol. 10, no. 19, pp. 3480-3493, 2010.

[99] Y. H. Lue, A. P. Sinha Hikim, R. S. Swerdloff et al., "Single exposure to heat induces stage-specific germ cell apoptosis in rats: role of intratesticular testosterone on stage specificity," Endocrinology, vol. 140, no. 4, pp. 1709-1717, 1999.

[100] Y. Zhang, X. Yang, H. Cao, Z. Chen, Y. Du, and W. Kong, "Heat stress induces $\mathrm{Cdc} 2$ protein decrease prior to mouse spermatogenic cell apoptosis," Acta Histochemica, vol. 110, no. 4, pp. 276-284, 2008.

[101] G. S. Waites and B. P. Setchell, "Physiology of mammalian testis," in Marshall's Physiology of Reproduction, G. Lamming, Ed., pp. 1-106, Churchill Livingstone, New York, NY, USA, 1990.

[102] Y. Yin, B. C. Stahl, W. C. DeWolf, and A. Morgentaler, "Heat-induced testicular apoptosis occurs independently of hormonal depletion," Apoptosis, vol. 3, no. 4, pp. 281-287, 1998.

[103] Y. H. Lue, B. L. Lasley, L. S. Laughlin et al., "Mild testicular hyperthermia induces profound transitional spermatogenic suppression through increased germ cell apoptosis in adult Cynomolgus monkeys (Macaca fascicularis)," Journal of Andrology, vol. 23, no. 6, pp. 799-805, 2002.

[104] A. P. Sinha Hikim, Y. Lue, C. M. Yamamoto et al., "Key apoptotic pathways for heat-induced programmed germ cell death in the testis," Endocrinology, vol. 144, no. 7, pp. 31673175, 2003.

[105] S. Matsuki, Y. Iuchi, Y. Ikeda, I. Sasagawa, Y. Tomita, and J. Fujii, "Suppression of cytochrome c release and apoptosis in testes with heat stress by minocycline," Biochemical and Biophysical Research Communications, vol. 312, no. 3, pp. 843-849, 2003.

[106] Y. Vera, M. Diaz-Romero, S. Rodriguez et al., "Mitochondriadependent pathway is involved in heat-induced male germ cell death: lessons from mutant mice," Biology of Reproduction, vol. 70, no. 5, pp. 1534-1540, 2004.

[107] Y. Jia, J. Castellanos, C. Wang et al., "Mitogen-activated protein kinase signaling in male germ cell apoptosis in the rat," Biology of Reproduction, vol. 80, no. 4, pp. 771-780, 2009.

[108] Y. Vera, S. Rodriguez, M. Castanares et al., "Functional role of caspases in heat-induced testicular germ cell apoptosis," Biology of Reproduction, vol. 72, no. 3, pp. 516-522, 2005.

[109] K. Makker, A. Agarwal, and R. Sharma, "Oxidative stress \& male infertility," Indian Journal of Medical Research, vol. 129, no. 4, pp. 357-367, 2009.

[110] S. C. Sikka, "Relative impact of oxidative stress on male reproductive function," Current Medicinal Chemistry, vol. 8, no. 7, pp. 851-862, 2001.

[111] A. Kumagai, H. Kodama, J. Kumagai et al., "Xanthine oxidase inhibitors suppress testicular germ cell apoptosis induced by experimental cryptorchidism," Molecular Human Reproduction, vol. 8, no. 2, pp. 118-123, 2002.

[112] B. G. Hill, B. P. Dranka, S. M. Bailey, J. R. Lancaster, and V. M. Darley-Usmar, "What part of NO don't you understand? Some answers to the cardinal questions in nitric oxide biology," Journal of Biological Chemistry, vol. 285, no. 26, pp. 19699-19704, 2010.

[113] P. Pacher, J. S. Beckman, and L. Liaudet, "Nitric oxide and peroxynitrite in health and disease," Physiological Reviews, vol. 87, no. 1, pp. 315-424, 2007.
[114] P. Calcerrada, G. Peluffo, and R. Radi, "Nitric oxide-derived oxidants with a focus on peroxynitrite: molecular targets, cellular responses and therapeutic implications," Current Pharmaceutical Design, vol. 17, no. 35, pp. 3905-3932, 2011.

[115] J. Guo, Y. Jia, S. X. Tao et al., "Expression of nitric oxide synthase during germ cell apoptosis in testis of cynomolgus monkey after testosterone and heat treatment," Journal of Andrology, vol. 30, no. 2, pp. 190-199, 2009.

[116] A. Nakai, M. Suzuki, and M. Tanabe, "Arrest of spermatogenesis in mice expressing an active heat shock transcription factor 1," EMBO Journal, vol. 19, no. 7, pp. 1545-1554, 2000.

[117] L. Somwaru, S. Li, L. Doglio, E. Goldberg, and B. R. Zirkin, "Heat-induced apoptosis of mouse meiotic cells is suppressed by ectopic expression of testis-specific calpastatin," Journal of Andrology, vol. 25, no. 4, pp. 506-513, 2004.

[118] M. Chen, J. X. Yuan, Y. Q. Shi et al., "Effect of $43 \circ \mathrm{C}$ treatment on expression of heat shock proteins 105, 70 and 60 in cultured monkey Sertoli cells," Asian Journal of Andrology, vol. 10, no. 3, pp. 474-485, 2008.

[119] K. De Gendt, J. V. Swinnen, P. T. K. Saunders et al., "A Sertoli cell-selective knockout of the androgen receptor causes spermatogenic arrest in meiosis," Proceedings of the National Academy of Sciences of the United States of America, vol. 101, no. 5, pp. 1327-1332, 2004.

[120] C. Chang, Y. T. Chen, S. D. Yeh et al., "Infertility with defective spermatogenesis and hypotestosteronemia in male mice lacking the androgen receptor in Sertoli cells," Proceedings of the National Academy of Sciences of the United States of America, vol. 101, no. 18, pp. 6876-6881, 2004.

[121] E. Herrera, K. Salas, N. Lagos, D. J. Benos, and J. G. Reyes, "Energy metabolism and its linkage to intracellular $\mathrm{Ca}^{2+}$ and $\mathrm{pH}$ regulation in rat spermatogenic cells," Biology of the Cell, vol. 92, no. 6, pp. 429-440, 2000.

[122] J. G. Reyes, N. Osses, M. Knox, A. Darszon, and C. L. Treviño, "Glucose and lactate regulate maitotoxin-activated $\mathrm{Ca}^{2+}$ entry in spermatogenic cells: the role of intracellular $\left[\mathrm{Ca}^{2+}\right], "$ FEBS Letters, vol. 584, no. 14, pp. 3111-3115, 2010.

[123] C. Lizama, I. Alfaro, J. G. Reyes, and R. D. Moreno, "Upregulation of CD95 (Apo-1/Fas) is associated with spermatocyte apoptosis during the first round of spermatogenesis in the rat," Apoptosis, vol. 12, no. 3, pp. 499-512, 2007.

[124] S. Wang, P. Song, and M.-H. Zou, "AMP-activated protein kinase, stress responses and cardiovascular diseases," Clinical Science, vol. 122, no. 12, pp. 555-573, 2012.

[125] R. A. Zager, D. S. Conrad, and K. Burkhart, "Phospholipase A2: a potentially important determinant of adenosine triphosphate levels during hypoxic-reoxygenation tubular injury," Journal of the American Society of Nephrology, vol. 7, no. 11, pp. 2327-2339, 1996.

[126] E. Tanaka, S. Niiyama, S. Sato, A. Yamada, and H. Higashi, "Arachidonic acid metabolites contribute to the irreversible depolarization induced by in vitro ischemia," Journal of Neurophysiology, vol. 90, no. 5, pp. 3213-3223, 2003.

[127] I. H. Lambert and S. F. Pedersen, "Multiple PLA2 isoforms regulate taurine release in NIH3T3 mouse fibroblasts," Advances in Experimental Medicine and Biology, vol. 583, pp. 99-108, 2006.

[128] E. A. Jannini, S. Ulisse, S. Cecconi et al., "Follicle-stimulating hormone-induced phospholipase A2 activity and eicosanoid generation in rat sertoli cells," Biology of Reproduction, vol. 51, no. 1, pp. 140-145, 1994. 
[129] J. Lee, J. H. Richburg, S. C. Younking, and K. Boekelheide, "The Fas system is a key regulator of germ cell apoptosis in the testis," Endocrinology, vol. 138, no. 5, pp. 2081-2088, 1997.

[130] S. Ulisse, B. Cinque, G. Silvano et al., "Erk-dependent cytosolic phospholipase A2 activity is induced by CD95 ligand cross-linking in the mouse derived Sertoli cell line TM4 and is required to trigger apoptosis in CD95 bearing cells," Cell Death and Differentiation, vol. 7, no. 10, pp. 916-924, 2000.

[131] Y. Gat, M. Gornish, and S. Joshua, "Erect posture of humans leads to male infertility, $\mathrm{BPH}$ and prostate cancer," Andrologia, vol. 44, no. 3, pp. 145-146, 2012.

[132] Y. Gat, M. Gornish, U. Navon, J. Chakraborty, G. N. Bachar, and I. Ben-Shlomo, "Right varicocele and hypoxia, crucial factors in male infertility: fluid mechanics analysis of the impaired testicular drainage system," Reproductive BioMedicine Online, vol. 13, no. 4, article 2380, pp. 510-515, 2006.

[133] M. A. Will, J. Swain, M. Fode, J. Sonksen, G. M. Christman, and D. Ohl, "The great debate: varicocele treatment and impact on fertility," Fertility and Sterility, vol. 95, no. 3, pp. 841-852, 2011.

[134] K. Shiraishi, H. Matsuyama, and H. Takihara, "Pathophysiology of varicocele in male infertility in the era of assisted reproductive technology," International Journal of Urology, vol. 19, no. 6, pp. 538-550, 2012.

[135] F. Kilinç, F. Kayaselcuk, C. Aygun, S. Guvel, T. Egilmez, and H. Ozkardes, "Experimental varicocele induces hypoxia inducible factor- $1 \alpha$, vascular endothelial growth factor expression and angiogenesis in the rat testis," Journal of Urology, vol. 172, no. 3, pp. 1188-1191, 2004.

[136] J. S. Paick, K. Park, S. W. Kim et al., "Increased expression of hypoxia-inducible factor- $1 \alpha$ and connective tissue growth factor accompanied by fibrosis in the rat testis of varicocele," Actas Urologicas Espanolas, vol. 36, no. 5, pp. 282-288, 2012.

[137] K. Shiraishi and K. Naito, "Involvement of vascular endothelial growth factor on spermatogenesis in testis with varicocele," Fertility and Sterility, vol. 90, no. 4, pp. 1313-1316, 2008.

[138] A. Merla, A. Ledda, L. Di Donato, S. Di Luzio, and G. L. Romani, "Use of infrared functional imaging to detect impaired thermoregulatory control in men with asymptomatic varicocele," Fertility and Sterility, vol. 78, no. 1, pp. 199-200, 2002.

[139] E. J. Wright, G. P. H. Young, and M. Goldstein, "Reduction in testicular temperature after varicocelectomy in infertile men," Urology, vol. 50, no. 2, pp. 257-259, 1997.

[140] T. Mostafa, T. H. Anis, A. El-Nashar, H. Imam, and I. A. Othman, "Varicocelectomy reduces reactive oxygen species levels and increases antioxidant activity of seminal plasma from infertile men with varicocele," International Journal of Andrology, vol. 24, no. 5, pp. 261-265, 2001.

[141] R. Dada, M. B. Shamsi, S. Venkatesh, N. P. Gupta, and R. Kumar, "Attenuation of oxidative stress \& DNA damage in varicocelectomy: implications in infertility management," Indian Journal of Medical Research, vol. 132, no. 12, pp. 728730, 2010.

[142] K. Shiraishi, H. Takihara, and H. Matsuyama, "Elevated scrotal temperature, but not varicocele grade, reflects testicular oxidative stress-mediated apoptosis," World Journal of Urology, vol. 28, no. 3, pp. 359-364, 2010.

[143] A. Agarwal, S. Prabakaran, and S. S. S. R. Allamaneni, "Relationship between oxidative stress, varicocele and infertility: a meta-analysis," Reproductive BioMedicine Online, vol. 12, no. 5, article 2200, pp. 630-633, 2006.

[144] A. Agarwal, K. Makker, and R. Sharma, "Clinical relevance of oxidative stress in male factor infertility: an update," American Journal of Reproductive Immunology, vol. 59, no. 1, pp. 2-11, 2008.

[145] C. J. Yoon, H. J. Park, and N. C. Park, "Reactive oxygen species in the internal spermatic and brachial veins of patients with varicocele-induced infertility," Korean Journal of Urology, vol. 51, no. 5, pp. 348-353, 2010.

[146] J. J. Lysiak, Q. A. T. Nguyen, and T. T. Turner, "Peptide and nonpeptide reactive oxygen scavengers provide partial rescue of the testis after torsion," Journal of Andrology, vol. 23, no. 3, pp. 400-409, 2002.

[147] S. S. R. Allamaneni, C. K. Naughton, R. K. Sharma, A. J. Thomas, and A. Agarwal, "Increased seminal reactive oxygen species levels in patients with varicoceles correlate with varicocele grade but not with testis size," Fertility and Sterility, vol. 82, no. 6, pp. 1684-1686, 2004.

[148] T. Mostafa, T. Anis, A. El Nashar, H. Imam, and I. Osman, "Seminal plasma reactive oxygen species-antioxidants relationship with varicocele grade," Andrologia, vol. 44, no. 1, pp. 66-69, 2012.

[149] U. O. Zorba, O. M. Sanli, M. Tezer, F. Erdemir, S. Shavakhabov, and A. Kadioglu, "Effect of infertility duration on postvaricocelectomy sperm counts and pregnancy rates," Urology, vol. 73, no. 4, pp. 767-771, 2009.

[150] I. T. Köksal, T. Erdoğru, H. Gülkesen et al., "The potential role of inducible nitric oxide synthase (iNOS) activity in the testicular dysfunction associated with varicocele: an experimental study," International Urology and Nephrology, vol. 36, no. 1, pp. 67-72, 2004.

[151] Z. Sahin, C. Celik-Ozenci, G. Akkoyunlu et al., "Increased expression of interleukin- $1 \alpha$ and interleukin- $1 \beta$ is associated with experimental varicocele," Fertility and Sterility, vol. 85, supplement 1, pp. 1265-1275, 2006.

[152] A. Fazlioglu, I. Yilmaz, O. Mete et al., "The effect of varicocele repair on experimental varicocele-induced testicular germ cell apoptosis," Journal of Andrology, vol. 29, no. 1, pp. 2934,2008

[153] S. Ueda, H. Masutani, H. Nakamura, T. Tanaka, M. Ueno, and J. Yodoi, "Redox control of cell death," Antioxidants and Redox Signaling, vol. 4, no. 3, pp. 405-414, 2002.

[154] J. Matsukawa, A. Matsuzawa, K. Takeda, and H. Ichijo, "The ASK1-MAP kinase cascades in mammalian stress response," Journal of Biochemistry, vol. 136, no. 3, pp. 261-265, 2004.

[155] C. Lizama, C. F. Lagos, R. Lagos-Cabré et al., "Calpain inhibitors prevent p38 MAPK activation and germ cell apoptosis after heat stress in pubertal rat testes," Journal of Cellular Physiology, vol. 221, no. 2, pp. 296-305, 2009.

[156] K. Shiraishi and K. Naito, "Effects of 4-hydroxy-2-nonenal, a marker of oxidative stress, on spermatogenesis and expression of p53 protein in male infertility," Journal of Urology, vol. 178, no. 3, pp. 1012-1017, 2007.

[157] J. D. Lee, T. H. Lee, W. H. Cheng, and S. Y. Jeng, "Involved intrinsic apoptotic pathway of testicular tissues in varicoceleinduced rats," World Journal of Urology, vol. 27, no. 4, pp. 527-532, 2009.

[158] F. W. Chang, G. H. Sun, Y. Y. Cheng, I. C. Chen, H. H. Chien, and G. J. Wu, "Effects of varicocele upon the expression of apoptosis-related proteins," Andrologia, vol. 42, no. 4, pp. 225-230, 2010. 
[159] I. Y. Chang, J. H. Kim, K. H. Park, and S. P. Yoon, "Experimental varicocele induces p53-dependent germ cell apoptosis through activation of $\gamma$-H2AX," Urologia Internationalis, vol. 85, no. 2, pp. 216-220, 2010.

[160] S. J. Workman and B. A. Kogan, "Old and new aspects of testicular torsion," Seminars in Urology, vol. 6, no. 2, pp. 146-157, 1988.

[161] J. Cubillos, J. S. Palmer, S. C. Friedman, J. Freyle, F. C. Lowe, and L. S. Palmer, "Familial testicular torsion," Journal of Urology, vol. 185, no. 6, pp. 2469-2472, 2011.

[162] J. J. Lysiak, Q. A. T. Nguyen, and T. T. Turner, "Fluctuations in rat testicular interstitial oxygen tensions are linked to testicular vasomotion: persistence after repair of torsion," Biology of Reproduction, vol. 63, no. 5, pp. 1383-1389, 2000.

[163] T. T. Turner, H. J. Bang, and J. L. Lysiak, "The molecular pathology of experimental testicular torsion suggests adjunct therapy to surgical repair," Journal of Urology, vol. 172, no. 6, pp. 2574-2578, 2004.

[164] T. T. Turner, H. J. Bang, and J. J. Lysiak, "Experimental testicular torsion: reperfusion blood flow and subsequent testicular venous plasma testosterone concentrations," Urology, vol. 65, no. 2, pp. 390-394, 2005.

[165] E. Ringdahl and L. Teague, "Testicular torsion," American Family Physician, vol. 74, no. 10, pp. 1739-1746, 2006.

[166] J. J. Lysiak, S. Zheng, R. Woodson, and T. T. Turner, "Caspase9-dependent pathway to murine germ cell apoptosis: mediation by oxidative stress, BAX, and caspase 2," Cell and Tissue Research, vol. 328, no. 2, pp. 411-419, 2007.

[167] T. T. Turner and J. L. Lysiak, "Oxidative stress: a common factor in testicular dysfunction," Journal of Andrology, vol. 29, no. 5, pp. 488-498, 2008.

[168] J. J. Lysiak, S. D. Turner, Q. A. T. Nguyen, K. Singbartl, K. Ley, and T. T. Turner, "Essential role of neutrophils in germ cell-specific apoptosis following ischemia/reperfusion injury of the mouse testis," Biology of Reproduction, vol. 65, no. 3, pp. 718-725, 2001.

[169] J. J. Lysiak, Q. A. T. Nguyen, J. L. Kirby, and T. T. Turner, "Ischemia-reperfusion of the murine testis stimulates the expression of proinflammatory cytokines and activation of cjun N-terminal kinase in a pathway to E-selectin expression," Biology of Reproduction, vol. 69, no. 1, pp. 202-210, 2003.

[170] X. Bustamante-Marín, C. Quiroga, S. Lavandero, J. G. Reyes, and R. D. Moreno, "Apoptosis, necrosis and autophagy are influenced by metabolic energy sources in cultured rat spermatocytes," Apoptosis, vol. 17, no. 6, pp. 539-550, 2012.

[171] J. J. Lysiak, S. D. Turner, and T. T. Turner, "Molecular pathway of germ cell apoptosis following ischemia/reperfusion of the rat testis," Biology of Reproduction, vol. 63, no. 5, pp. 14651472, 2000.

[172] I. Sukhotnik, K. Voskoboinik, M. Lurie, Y. Bejar, A. G. Coran, and J. G. Mogilner, "Involvement of the bax and bcl-2 system in the induction of germ cell apoptosis is correlated with the time of reperfusion after testicular ischemia in a rat model," Fertility and Sterility, vol. 92, no. 4, pp. 1466-1469, 2009.

[173] K. Shiraishi, K. Naito, and K. I. Yoshida, "Inhibition of calpain but not caspase protects the testis against injury after experimental testicular torsion of rat," Biology of Reproduction, vol. 63, no. 5, pp. 1538-1548, 2000.

[174] J. J. Lysiak, "The role of tumor necrosis factor-alpha and interleukin-1 in the mammalian testis and their involvement in testicular torsion and autoimmune orchitis," Reproductive Biology and Endocrinology, vol. 2, article 9, 2004.
[175] S. K. De, H. L. Chen, J. L. Pace, J. S. Hunt, P. F. Terranova, and G. C. Enders, "Expression of tumor necrosis factor- $\alpha$ in mouse spermatogenic cells," Endocrinology, vol. 133, no. 1, pp. 389-396, 1993.

[176] R. D. Moreno, P. Urriola-Munoz, and R. Lagos-Cabre, "The emerging role of matrix metalloproteases of the ADAM family in male germ cell apoptosis," Spermatogenesis, vol. 1, pp. 195-208, 2011.

[177] C. Lizama, D. Rojas-Benítez, M. Antonelli et al., "TACE/ ADAM17 is involved in germ cell apoptosis during rat spermatogenesis," Reproduction, vol. 140, no. 2, pp. 305-317, 2010.

[178] C. Lizama, A. Ludwig, and R. D. Moreno, "Etoposide induces apoptosis and upregulation of TACE/ADAM17 and ADAM10 in an in vitro male germ cell line model," Biochimica et Biophysica Acta, vol. 1813, no. 1, pp. 120-128, 2011.

[179] C. Lizama, D. Rojas-benitez, M. Antonelli, A. Ludwig, and R. D. Moreno, "Involvement of TACE/ADAM17 and ADAM10 in etoposide-induced apoptosis of germ cells in rat spermatogenesis," Journal of Cellular Physiology, vol. 227, no. 2, pp. 829-838, 2012.

[180] W. Eggert-Kruse, I. Kiefer, C. Beck, T. Demirakca, and T. Strowitzki, "Role for tumor necrosis factor alpha (TNF- $\alpha$ ) and interleukin 1-beta (IL-1 $\beta$ ) determination in seminal plasma during infertility investigation," Fertility and Sterility, vol. 87, no. 4, pp. 810-823, 2007.

[181] S. Seshadri, M. Bates, G. Vince, and D. I. L. Jones, "The role of cytokine expression in different subgroups of subfertile men," American Journal of Reproductive Immunology, vol. 62, no. 5, pp. 275-282, 2009.

[182] E. Martínez-Prado and M. I. Camejo Bermúdez, "Expression of IL-6, IL-8, TNF- $\alpha$, IL-10, HSP-60, anti-HSP-60 antibodies, and anti-sperm antibodies, in semen of men with leukocytes and/or bacteria," American Journal of Reproductive Immunology, vol. 63, no. 3, pp. 233-243, 2010.

[183] H. V. Edwards, J. D. Scott, and G. S. Baillie, "PKA phosphorylation of the small heat-shock protein Hsp20 enhances its cardioprotective effects," Biochemical Society Transactions, vol. 40, no. 1, pp. 210-214, 2012.

[184] H. Ji, X.-D. Shen, Y. Zhang et al., "Activation of cyclic adenosine monophosphate-dependent protein kinase a signaling prevents liver ischemia/reperfusion injury in mice," Liver Transplantation, vol. 18, no. 6, pp. 659-670, 2012. 


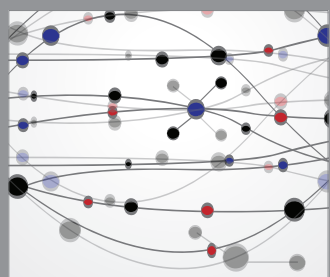

The Scientific World Journal


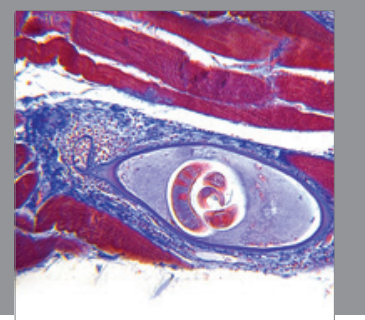

Gastroenterology

Research and Practice
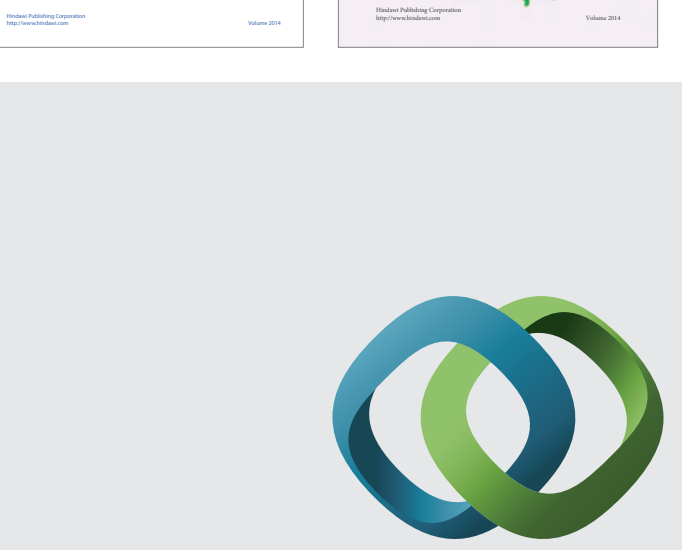

\section{Hindawi}

Submit your manuscripts at

http://www.hindawi.com
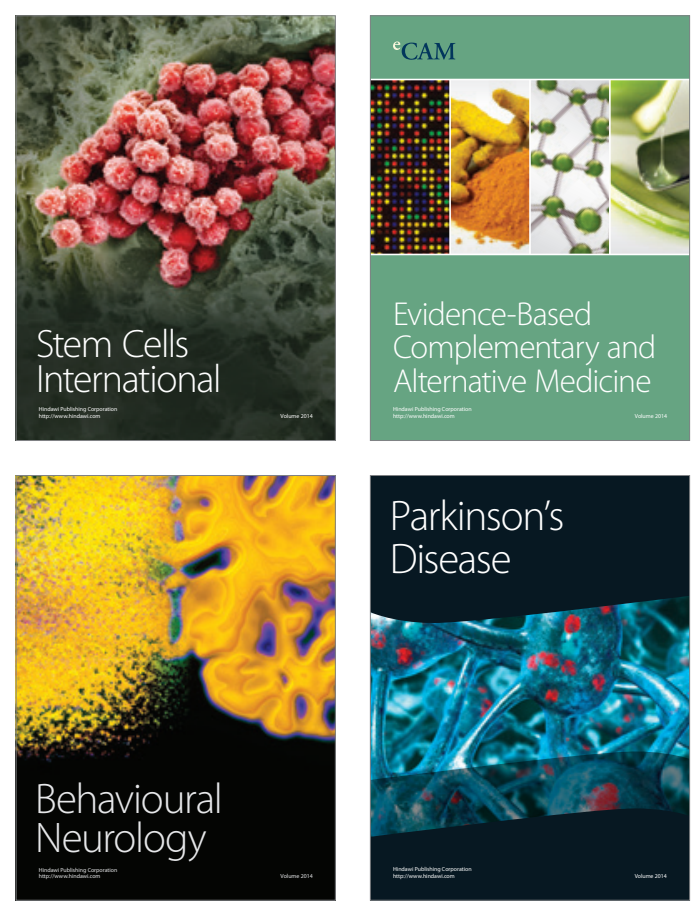

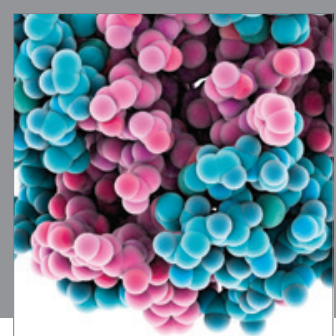

Journal of
Diabetes Research

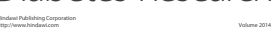

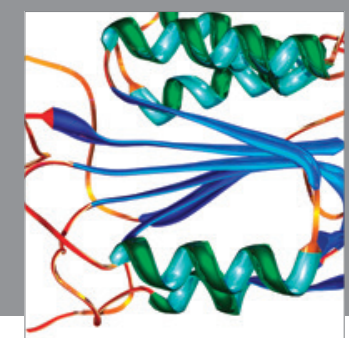

Disease Markers
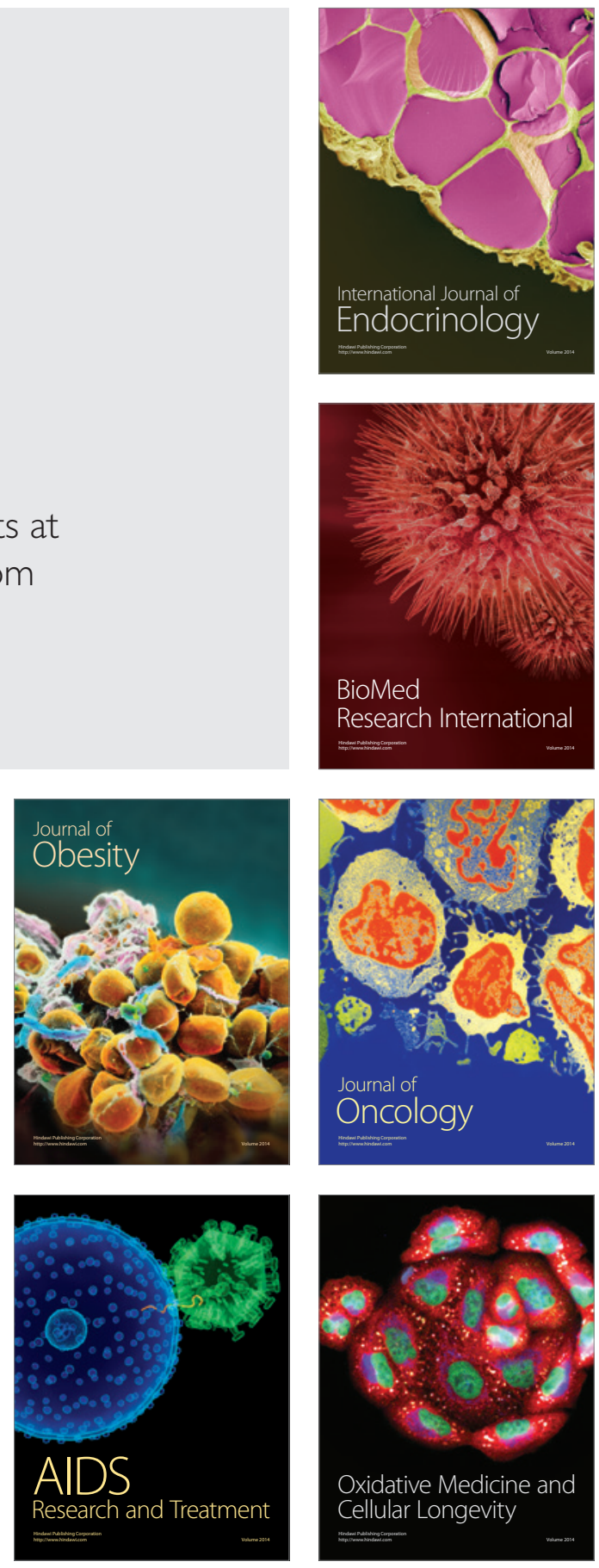